\title{
REVIEW
}

\section{AR-dependent phosphorylation and phospho-proteome targets in prostate cancer}

\author{
Varadha Balaji Venkadakrishnan ${ }^{1,2}$, Salma Ben-Salem¹ and Hannelore V Heemers \\ 'Department of Cancer Biology, Cleveland Clinic, Cleveland, Ohio, USA \\ 2Department of Biological, Geological and Environmental Sciences, Cleveland State University, Cleveland, Ohio, USA
}

Correspondence should be addressed to H V Heemers: heemerh@ccf.org

\begin{abstract}
Prostate cancer (CaP) is the second leading cause of cancer-related deaths in Western men. Because androgens drive CaP by activating the androgen receptor (AR), blocking AR's ligand activation, known as androgen deprivation therapy (ADT), is the default treatment for metastatic CaP. Despite an initial remission, CaP eventually develops resistance to ADT and progresses to castration-recurrent CaP (CRPC). CRPC continues to rely on aberrantly activated AR that is no longer inhibited effectively by available therapeutics. Interference with signaling pathways downstream of activated AR that mediate aggressive CRPC behavior may lead to alternative CaP treatments. Developing such therapeutic strategies requires a thorough mechanistic understanding of the most clinically relevant and druggable AR-dependent signaling events. Recent proteomics analyses of CRPC clinical specimens indicate a shift in the phosphoproteome during CaP progression. Kinases and phosphatases represent druggable entities, for which clinically tested inhibitors are available, some of which are incorporated already in treatment plans for other human malignancies. Here, we reviewed the AR-associated transcriptome and translational regulon, and AR interactome involved in CaP phosphorylation events. Novel and for the most part mutually exclusive AR-dependent transcriptional and posttranscriptional control over kinase and phosphatase expression was found, with yet other phospho-regulators interacting with AR. The multiple mechanisms by which AR can shape and fine-tune the CaP phosphoproteome were reflected in diverse aspects of CaP biology such as cell cycle progression and cell migration. Furthermore, we examined the potential, limitations and challenges of interfering with AR-mediated phosphorylation events as alternative strategy to block AR function during CaP progression.
\end{abstract}

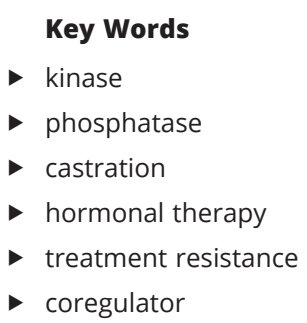

Endocrine-Related Cance (2020) 27, R193-R210

\section{Introduction}

Prostate cancer (CaP) is expected to cause the death of 33,300 American men in 2020 and remains the second leading cause of cancer-related deaths in Western men (Siegel et al. 2020). It is well recognized that the androgen receptor (AR), a ligand-activated transcription factor, drives CaP progression (Huggins \& Hodges 2002, Dai et al. 2017). Therefore, blocking AR activation, known as androgen deprivation therapy (ADT), has been the default treatment for metastatic $\mathrm{CaP}$ for almost 80 years. Although ADT is successful in inducing an initial remission, CaP cells eventually adapt to acquire resistance to ADT, and castration-recurrent CaP (CRPC) develops. Adaptations that allow the emergence of CRPC include several mechanisms by which AR activation is restored, 
such as activating somatic mutations, amplifications and rearrangements in the AR gene, intratumoral metabolism and synthesis of (precursor) androgens, compensatory expression of the AR-related glucocorticoid receptor that is able to take over parts of AR function, all of which have been the subject of excellent reviews before (Mills 2014, Watson et al. 2015, Narayanan et al. 2016, Dai et al. 2017).

Because AR is still active and continues to drive CaP progression after failure of ADT, alternative means of interfering with its activity are sought. In view of AR's transcription factor function such efforts have mostly focused on its ligand-independent constitutively active transcription activity, its ability to bind DNA, and to form active transcriptional complexes. Several compounds targeting these aspects of AR function have been developed and/or tested clinically, yet none have moved into clinic (Kumari et al. 2017, Senapati et al. 2019).

Recent genomic and proteomics analyses of CaP models and clinical specimens have provided substantial new evidence for critical roles for AR in various cellular events relevant to aggressive $\mathrm{CaP}$ behavior and $\mathrm{CaP}$ progression such as cell cycle regulation, epigenetic modifications, DNA repair, and translational regulation (Schiewer et al. 2012, Xu et al. 2012, Schiewer \& Knudsen 2016, 2019, Liu et al. 2019). While delineating the involvement of AR in these cellular processes, it has become clear that AR controls several phosphorylation events in which specific kinases and phosphatases play important roles. In other human malignancies, defining and understanding the phosphorylation-based signaling cascades that drive disease progression resulted in novel therapeutic strategies, some of which have shown exceptional success rates for therapeutic intervention and overcoming treatment resistance (Lynch et al. 2004, Chapman et al. 2011, Shaw et al. 2014). For instance, in non-small cell lung cancer, the tyrosine kinase inhibitors gefitinib or erlotinib are effective in targeting activating mutations in EGF receptor (EGFR), a driver of disease progression (Ciardiello \& Tortora 2008). Upon emergence of somatic mutations, second- or even thirdgeneration EGFR inhibitors are used to improve outcomes (Janjigian et al. 2014, Mok et al. 2017). The possibility of similar therapeutic successes targeting phosphorylation regulators in $\mathrm{CaP}$ is supported by the emerging phosphoproteomic characterizations of clinical CRPC specimens (Drake et al. 2016 Faltermeier et al. 2016) and testing of kinase inhibiting drugs, alone or in combination therapy, in CaP co-clinical trials (Munster et al. 2019, Sweeney et al . 2019).

Here, we review information on AR's control over kinase and phosphatase expression and its collaboration with such key regulators of phosphorylation events in $\mathrm{CaP}$. We explore the biology that is impacted by AR-associated phosphorylation, its relevance during $\mathrm{CaP}$ progression, and the overall potential, limitations and challenges associated with exploiting AR-dependent phosphorylation as alternative strategy to overcome resistance to AR-targeting treatments in CaP (Fig. 1).

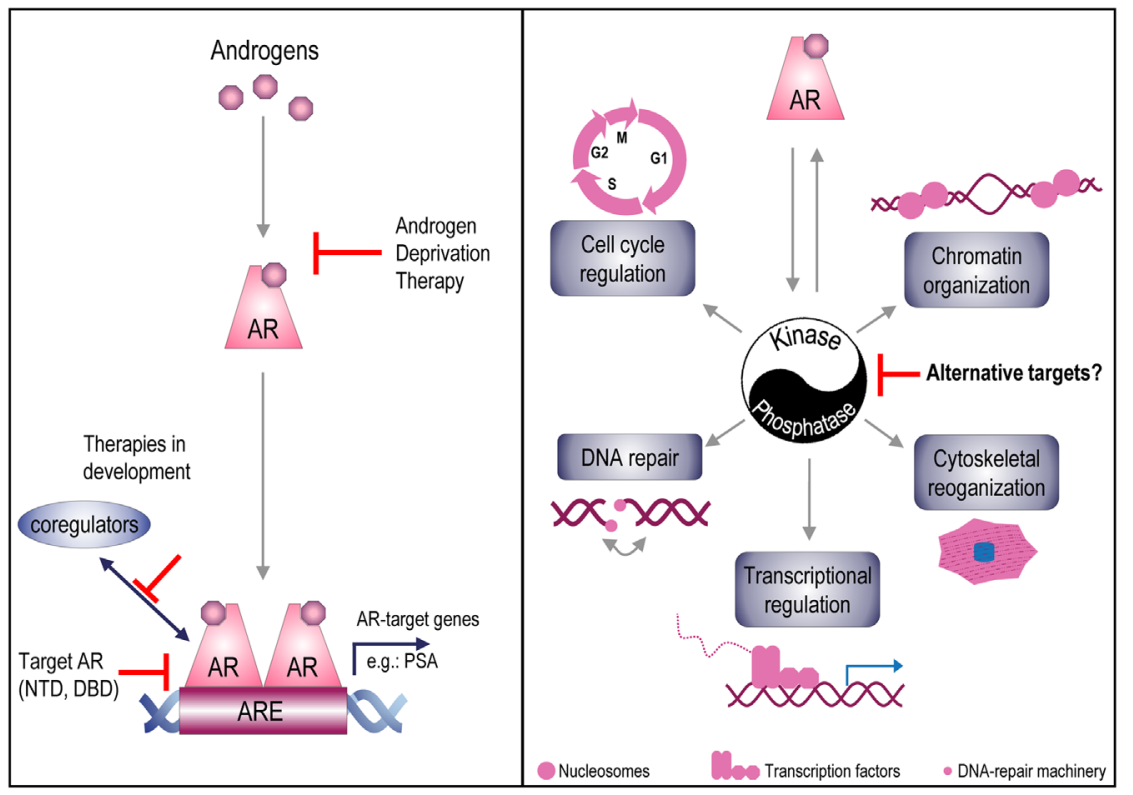

\section{Figure 1}

Differential AR action in CaP. Canonical AR signaling (left panel). Androgens bind to and activate AR. Activated AR homodimerizes, relocates to the nucleus and binds to androgen response elements (AREs) where it interacts with coregulators to transcribe target genes such as the gene encoding prostate-specific antigen (PSA). Androgen deprivation therapy, the first-line standard of care for metastatic CaP, blocks ligand-activation of AR. Treatment strategies to block AR's transcription function in an alternative manner include inhibiting AR-coregulator interactions, AR's constitutively active transcription by the $\mathrm{N}$-terminal domain (NTD), and AR-DNA binding via the DNA-binding domain (DBD) of AR. Schematic representing AR's regulation of several cellular processes via its control over and interactions with kinases and phosphatases (right panel). https://erc bioscientifica com https://doi.org/10.1530/ERC-20-0048 (c) 2020 Society for Endocrinology Published by Bioscientifica Ltd. Printed in Great Britain 


\section{AR dependence of kinase and phosphatase expression and activity}

Control of AR over important phosphorylation events and AR's collaboration with kinases and phosphatases in $\mathrm{CaP}$ has been recognized before. A few well-known examples that immediately come to mind are AR's regulation of cyclin-dependent kinase (CDK) activity and its interaction with epigenetic modifiers such as TRIM24 (a kinase) and the tumor suppressor PTEN, a phosphatase (Knudsen et al. 1998, Li et al. 2001, Groner et al. 2016). Yet, despite the emerging insights in the important role and the clinical relevance of the phospho-proteome during CRPC progression (Drake et al. 2012, 2013, 2016, Faltermeier et al. 2016), the extent of AR's contribution to phosphorylation events in $\mathrm{CaP}$ is yet to be fully appreciated. Here, we review literature to define more comprehensively the transcriptional and translational control by AR over kinase and phosphatase expression and to examine alternative mechanisms by which AR impacts phosphorylation-dependent CaP cell biology.

\section{Transcriptional control by AR over kinases and phosphatases}

First, we explored the possibility that AR regulates the CaP phosphoproteome by directly controlling transcription of genes that encode kinases or phosphatases. To this end, members of a $\mathrm{CaP}$ gene signature representing hundreds of bona fide AR target genes ( $n=452$, LNCaP cell dataset) (Liu et al. 2017), i.e., genes that contain at least one androgen response element (ARE) and whose androgen responsiveness has been experimentally verified were cross-matched with 536 kinases listed on KinHub (Eid et al. 2017), a resource that maintains and curates knowledge on the human kinome. This approach isolated 28 genes encoding kinases as direct AR target genes. Expression of 13 kinases was androgen-repressed, the remaining 15 were upregulated by AR stimulation. The majority $(n=23)$ of these genes encoded for Ser/Thr kinases, while only five led to Tyr kinase expression (Table 1). Kinases controlled transcriptionally by AR include for instance CAMKK2, a member of the CAMK family of kinases,

Table 1 AR-associated kinases.

\begin{tabular}{|c|c|c|c|c|c|}
\hline Gene symbol & AR dependence & Type & Family & Inhibitor & CaP phosphoproteome \\
\hline \multicolumn{6}{|c|}{ AR regulation: transcriptional } \\
\hline BMPR1A & Up & Ser/Thr & TKL & $\mathrm{DMH}-1$ & NA \\
\hline BMPR1B & Up & Ser/Thr & TKL & LDN-212854 & NA \\
\hline CAMKK2 & Up & Ser/Thr & CAMK & A 484954, NH125 & pS495, pS511c \\
\hline CDK8 & Down & Ser/Thr & CMGC & Senexin A & NA \\
\hline CDKL5 & Down & Ser/Thr & CMGC & None & NA \\
\hline CLK2 & Down & Ser/Thr & CMGC & TG003 & NA \\
\hline DDR1 & Down & Tyr & TK & DDR1-IN-1, nilotinib & Y520, Y792, Y796d \\
\hline ЕРНАЗ & Up & Tyr & TK & KB004 & Y596d \\
\hline $\mathrm{ERBB}^{\mathrm{a}}$ & Down & Tyr & TK & $>90$ inhibitors & pS1054, pS1078, pS1083c \\
\hline MAK1a & Up & Ser/Thr & CMGC & None & NA \\
\hline MAP2K4 & Up & Ser/Thr & STE & MEK inhibitors & pS257c \\
\hline MAP4K1 & Down & Ser/Thr & STE & None & NA \\
\hline MAPK6b & Up & Ser/Thr & CMGC & None & pS386, pT389e \\
\hline MAPK8 & Down & Ser/Thr & CMGC & None & pT183d \\
\hline MAPKAPK3 & Down & Ser/Thr & CAMK & None & NA \\
\hline MERTK & Up & Tyr & TK & None & NA \\
\hline MYLK & Down & Ser/Thr & CAMK & ML 9 Hydrochloride & pS911, pS1768c \\
\hline PAK2 & Down & Ser/Thr & STE & FRAX597 & $\mathrm{pS} 2, \mathrm{pS} 141^{\mathrm{c}}$ \\
\hline PRKAA1 & Up & Ser/Thr & CAMK & None & pS496c \\
\hline PRKCA & Up & Ser/Thr & AGC & None & pT638, pS657f \\
\hline PRKD1a & Down & Ser/Thr & CAMK & CID 2011756 & pS473e \\
\hline ROR1 & Up & Tyr & TK & None & NA \\
\hline RPS6KA1a & Down & Ser/Thr & AGC & BRD 7389 & $\mathrm{pS} 232 \mathrm{e}$ \\
\hline RPS6KA3a & Up & Ser/Thr & AGC & AT9283 & $\mathrm{pS} 221 \mathrm{e}$ \\
\hline SGK1a & Up & Ser/Thr & AGC & None & NA \\
\hline SNRK & Down & Ser/Thr & CAMK & None & NA \\
\hline STK17B & Up & Ser/Thr & CAMK & None & NA \\
\hline STK39 & Up & Ser/Thr & STE & None & pS385, pS315, pT354c \\
\hline
\end{tabular}

(Continued)

https://erc bioscientifica com https://doi.org/10.1530/ERC-20-0048 c) 2020 Society for Endocrinology Published by Bioscientifica Ltd. Printed in Great Britain 
Table 1 (Continued)

\begin{tabular}{|c|c|c|c|c|c|}
\hline Gene symbol & AR dependence & Type & Family & Inhibitor & CaP phosphoproteome \\
\hline \multicolumn{6}{|c|}{ AR regulation: translational } \\
\hline HIPKЗа & NA & Ser/Thr & CMGC & None & NA \\
\hline MAPK6b & NA & Ser/Thr & CMGC & None & pS386, pT389e \\
\hline MAPKAPK2 & NA & Ser/Thr & CAMK & PF-3644022 & NA \\
\hline PINK1 & NA & Ser/Thr & Other & None & NA \\
\hline TRIM24a & NA & Ser/Thr & Atypical & None & pS1028c \\
\hline \multicolumn{6}{|c|}{ AR regulation: interactor } \\
\hline AKT1 & NA & Ser/Thr & AGC & Nelfinavir, Everolimus, PHT 427 & pT34c \\
\hline CDK11B & NA & Ser/Thr & CMGC & None & pS265, pS271, pS422c \\
\hline CDK6 & NA & Ser/Thr & CMGC & LEE011 - CDK4/6 & NA \\
\hline CDK7 & NA & Ser/Thr & CMGC & Alvocidib, seliciclib, BS-181 & pS164g \\
\hline CDK9 & NA & Ser/Thr & CMGC & $\begin{array}{l}\text { Alvocidib, seliciclib, } \\
\text { Dinaciclib, AZD } 5438\end{array}$ & NA \\
\hline DAPK3 & NA & Ser/Thr & CAMK & None & NA \\
\hline DYRK1A & NA & Ser/Thr & CMGC & Harmine, INDY, ProINDY & pY321f \\
\hline EGFR & NA & Tyr & TK & >200 inhibitors & pS1039, pS1042c \\
\hline ERBB2 $^{\mathrm{a}}$ & NA & Tyr & TK & $>90$ inhibitors & pS1054, pS1078, pS1083c \\
\hline GAK & NA & Ser/Thr & Other & None & $\begin{array}{l}\text { pS16, pS73, pS826, pS829, } \\
\text { pS1185c }\end{array}$ \\
\hline GSK3B & NA & Ser/Thr & CMGC & SB 216763, AZD1080 & pY216d \\
\hline HIPK3a & NA & Ser/Thr & CMGC & None & NA \\
\hline LATS2 & NA & Ser/Thr & AGC & None & NA \\
\hline MAK1a & NA & Ser/Thr & CMGC & None & NA \\
\hline MAPK1 & NA & Ser/Thr & CMGC & FR 180204 & Y187d \\
\hline MAPK15 & NA & Ser/Thr & CMGC & None & NA \\
\hline NLK & NA & Ser/Thr & CMGC & None & NA \\
\hline PAK6 & NA & Ser/Thr & STE & None & pS560d \\
\hline PKN1 & NA & Ser/Thr & AGC & lestaurtinib, tofaticinib & ps69, ps916d \\
\hline PRKD1a & NA & Ser/Thr & CAMK & CID 2011756 & pS473e \\
\hline PRKDC & NA & Ser/Thr & Atypical & AZD7648, & pT2609, pS2612, pS3205d \\
\hline RNASEL & NA & Ser/Thr & Other & None & NA \\
\hline RPS6KA1a & NA & Ser/Thr & AGC & BRD 7389 & $\mathrm{pS} 232 \mathrm{e}$ \\
\hline RPS6KA3a & NA & Ser/Thr & AGC & AT9283 & pS221e \\
\hline SGK1a & NA & Ser/Thr & AGC & None & NA \\
\hline SRC & NA & Tyr & TK & Herbimycin A, MNS, Dasatinib & pS104e \\
\hline TAF1 & NA & Ser/Thr & Atypical & None & $\begin{array}{l}\text { pS1152, pS1155, pS1669, } \\
\text { pS1672e }\end{array}$ \\
\hline TNK2 & NA & Tyr & TK & AIM-100, Dasatinib & pY827e \\
\hline TRIM24a & NA & Ser/Thr & Atypical & None & pS1028c \\
\hline
\end{tabular}

Kinases that are transcriptionally (top part) or translationally (middle part) regulated by AR and kinases that interact with AR (bottom part). Up/down; kinase expression induced/repressed by AR. Inhibitors; commercially available kinase inhibitors, information obtained from genecards.org. CaP phosphoproteome; site of kinase phosphorylation in CRPC samples obtained from Drake et al. (2016) and Faltermeier et al. (2016).

aEntry occurs in top and bottom part of table; bentry occurs in top and middle part of table; cphosphorylation site is significantly enriched in CaP but functional consequence of phosphorylation is unknown; dphosphorylation site is significantly enriched in CaP and associated with kinase activation; ephosphorylation site is found but not significantly enriched in CaP and functional consequence of phosphorylation is unknown; fphosphorylation site not significantly enriched in CaP but activates the kinase; gphosphorylation site is significantly enriched in CaP and represses kinase activity.

AGC, members of PKA, PKG, and PKC family of kinases; CAMK, calcium/calmodulin-dependent kinase; CMGC, members of cyclin-dependent kinase mitogen-activated protein kinase, glycogen synthase kinase and CDC-like kinase famil; NA, not applicable; Ser/thr, serine/threonine kinase; STE, 'sterile' serine/threonine kinases; TK, tyrosine kinase; TKL, tyrosine kinase-like; Tyr, tyrosine kinase.

which is well known for its role in lipid metabolism, and has been proposed by several groups as viable therapeutic target in CaP (Massie et al. 2011, Karacosta et al. 2012, Penfold et al. 2018, White et al. 2018). Other more neglected kinases include the discoidin domain receptor family member 1, DDR1, which has been implicated in epithelial-mesenchymal transition (EMT) and metastasis in human cancers (Maeyama et al. 2008, Yeh et al. 2011, Koh et al. 2015), has not yet been extensively studied in CaP, but can be inhibited by nilotinib, a drug that is being tested in clinical trials for leukemia (Jeitany et al. 2018). Comparison with recent phospho-proteome data obtained via mass spectrometry on clinical CRPC cases (Drake et al. 2016) revealed several kinases, for instance https://erc.bioscientifica.com https://doi.org/10.1530/ERC-20-0048
C) 2020 Society for Endocrinology Published by Bioscientifica Ltd. Printed in Great Britain 
MERTK, to be over-activated in CaP compared to benign prostate, suggesting important roles in late-stage $\mathrm{CaP}$ and supporting their therapeutic potential. For several of these kinases, inhibitors have been developed, some of which have been tested or are being tested in clinical CaP trials, or have been used to treat other malignancies (Table 1).

These data demonstrate that a significant number of kinases is controlled by AR directly binding to their regulatory gene regions. We performed a similar examination of the AR target gene list for genes encoding any of the 226 phosphatases classified by the Human Gene Nomenclature Committee (HGNC). This analysis returned 13 AR-dependent and transcriptionally regulated phosphatases, consisting of 9 phosphatases that are androgen-stimulated and 4 that are downregulated upon $\mathrm{AR}$ activation, verifying that this class of proteins can be subject to similar AR regulation (Table 2). Among the 13 phosphatases were PTEN and INPP4B, which have been implicated in CaP progression before (Li et al. 1997, Hodgson et al. 2011, 2014), whereas others such as SYNJ1 have lesser recognized functions in CaP. Pharmacologic modulation of phosphatase activity is possible, as evidenced by availability of several phosphatase inhibitors; however, only a handful of them are in clinical trials (Bollu et al. 2017).

AR regulation of its target genes can be context dependent and may be influenced by, for instance, the genomic make-up or the AR expression levels of CaP cells. We therefore examined the extent to which the findings of AR dependence of genes encoding kinases and phosphatases derived from LNCaP cells can be extrapolated to other AR-positive cell lines, such as VCaP. VCaP cells express the TMPRSS2-ERG gene fusion and show AR gene amplification, which can each impact the composition of the AR cistrome (Waltering et al. 2009, Yu et al. 2010, Makkonen et al. 2011, Cai et al. 2013, Wasmuth et al. 2020). Analyses of two publically available and independent AR ChIP-Seq data sets derived from VCaP cells (Massie et al. 2011, Asangani et al. 2014) employing the same selection criteria used on LNCaP cell data (i.e. AR binding peaks present within $300 \mathrm{~kb}$ of transcriptional start sites (Liu et al. 2017)) revealed androgen-induced AR binding peaks in 27/28 kinase-encoding genes and all, or 13/13, phosphatase-encoding genes (Supplementary Table 1 , see section on supplementary materials given at the end of this article). Moreover, except for the gene encoding CLK2 (two thirds of replicates positive), AR-binding sites were present in all biological replicates in androgen-stimulated conditions, indicating that AR regulation of these kinases and phosphatases occurs in multiple AR-positive CaP models.

\section{Translational control by AR over kinases and phosphatases}

The impact of AR-dependent transcriptional control over its target genes is readily measured via oligoarray, RNA-Seq and similar gene expression assays, and can be validated using AR ChIP-chip, ChIP-Seq or ChIP-exo approaches. The AR-controlled transcriptome has therefore been well-documented and characterized in an array of $\mathrm{CaP}$ model systems as well as clinical specimens (Mills 2014, Kumari et al. 2017, Senapati et al. 2019). The extent to which AR-dependent transcription is translated into $\mathrm{CaP}$ proteomes or to which $\mathrm{CaP}$ translational events are AR-dependent is poorly understood. This is an important question since recent studies have shown discordance between mRNA levels and protein abundance (Sinha et al. 2019). The lack of our knowledge in this regard, particularly as it regards AR's control over CaP translation (rates), relates to the well-recognized, and not CaP-specific, limitations in the technical assessment of translational rates. The results from techniques such as polysome profiling, RiboSeq and ribosome profiling can serve as surrogate for translation rates, but until very recently these had not been used on CaP models, let alone in the context of CaP's AR dependency. A recent study found that 4EBP1, an inhibitor of the translation initiation complex, contains an ARE in its first intron, and upon androgen stimulation of CaP cells, 4EBP1 mRNA levels are induced (Liu et al. 2019). These findings point to an indirect mechanism for AR to shape the CaP proteome. Subsequently, ribosome profiling was done on $\mathrm{CaP}$ tissues from a transgenic mouse $\mathrm{CaP}$ model driven by prostate-specific PTEN deletion, which mimics aggressive CRPC progression. Tissues from intact versus castrated animals were analyzed, which allowed to verify AR dependence. The authors report a subset of mRNAs that are differentially regulated at the post-transcriptional level and are subject to AR signaling, which encode five kinases and three phosphatases (Tables 1 and 2). Remarkable, only one entry (i.e. MAPK6) overlapped between transcriptionally and post-transcriptionally AR-dependent genes, indicating distinct levels of AR control over the expression of phosphoregulators.

\section{Alternative AR involvement in kinase and phosphatase action}

Direct transcriptional or post-transcriptional control over kinase and phosphatase expression may not capture the full extent of AR's ability to regulate phosphorylation status of CaP cells. 
Table 2 AR-associated phosphatases.

\begin{tabular}{|c|c|}
\hline Gene symbol & AR dependence \\
\hline $\begin{array}{l}\text { AR regulation: } \\
\text { INPP4B }\end{array}$ & $\begin{array}{l}\text { Transcriptional } \\
\text { Up }\end{array}$ \\
\hline INPP5A & Down \\
\hline INPP5D & Down \\
\hline PMM2 & Up \\
\hline PPM1K & Up \\
\hline PPP1CB & Up \\
\hline PPP2CB & Up \\
\hline PTENb & Down \\
\hline PTPN11 & Up \\
\hline PTPN21 & Up \\
\hline PTPRM & Up \\
\hline PTPRR & Down \\
\hline SYNJ1 & Up \\
\hline AR regulation: & Translational \\
\hline MINPP1 & NA \\
\hline PHLPP1 & NA \\
\hline PPP4C & NA \\
\hline AR regulation: & Interactor \\
\hline CDC25A & NA \\
\hline CDC25B & NA \\
\hline CTDSP2 & NA \\
\hline PGAM5 & NA \\
\hline PPP1CA & NA \\
\hline PPP1CC & NA \\
\hline PTENb & NA \\
\hline
\end{tabular}

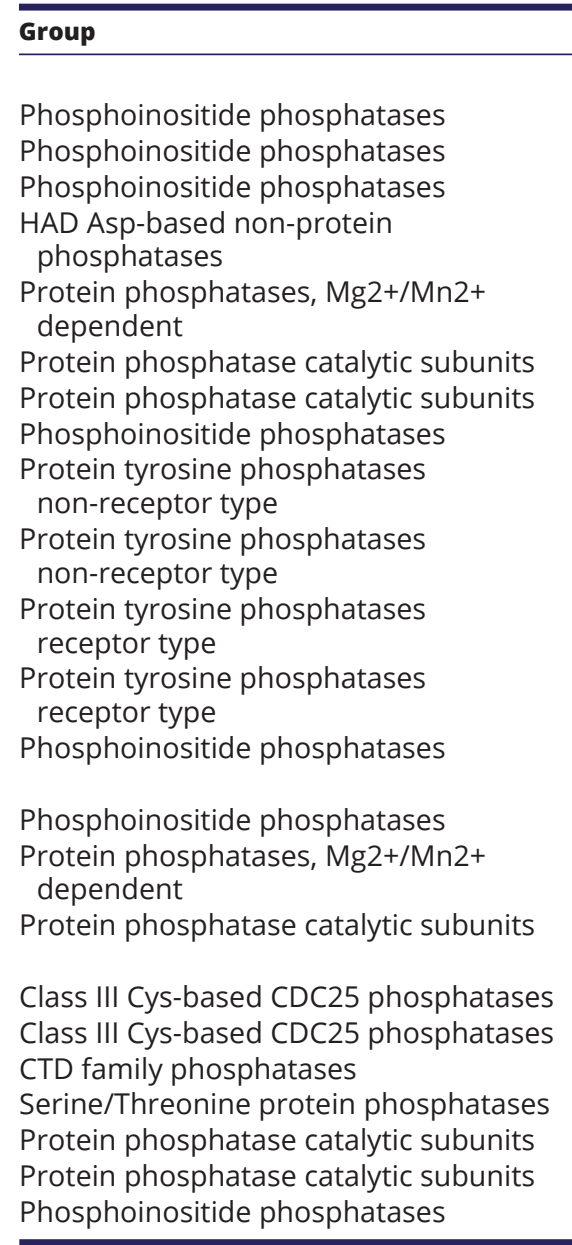

\begin{tabular}{l}
\hline Inhibitor \\
\hline None \\
None \\
None \\
None \\
None \\
FK 506 \\
FK 506 \\
SF1670 \\
BVT 948, TCS 401 \\
None \\
None \\
None \\
None \\
None \\
None \\
None \\
NSC 663284, NSC 95397 \\
NSC 663284, NSC 95397 \\
None \\
FK 506 \\
SF1670 506 \\
\end{tabular}

\begin{tabular}{l} 
CaP phosphoproteome \\
\hline NA \\
NA \\
pS971a \\
NA \\
NA \\
NA \\
NA \\
NA \\
pY584a \\
pS658c \\
NA \\
NA \\
pS830c \\
NA \\
NA \\
NA \\
NA \\
NA \\
pA \\
NA \\
NA \\
NA \\
\end{tabular}

Phosphatases that are transcriptionally (top part) or translationally (middle part) regulated by AR and phosphatase that interact with AR (bottom part). Up/down; phosphatase expression induced/repressed by AR. Inhibitors; commercially available kinase inhibitors, information obtained from genecards. org. CaP phosphoproteome; site of phosphorylation in CRPC samples obtained from Drake et al. (2016) and Faltermeier et al. (2016).

aPhosphorylation site is significantly enriched in CaP samples but consequence of phosphorylation is not defined; bentry occurs in top and bottom part of table; cPhosphorylation site is found but not significantly enriched in CaP samples and consequence of phosphorylation is not defined.

NA, not applicable.

\section{Mechanisms that involve genomic AR function}

It has been long recognized that the (de)phosphorylation activity of these regulators depends on activating ligands, interactions with adaptors, scaffold proteins and binding patterns that ensure their proper spatial and temporal activation and complex formation within the cell (Pawson \& Scott 1997) or E3 ligases that modulate their action. In CaP, several aspects of such 'indirect' modulation of kinase and phosphatase action may involve transcriptional or translational regulation by AR. For instance, AR stimulates the enzymatic pathways that govern synthesis of fatty acids (Heemers et al. 2006), which are critical activators of protein kinase C family members (Bell \& Burns 1991). Similarly, several adaptor proteins (e.g. GRB10) and scaffold proteins (e.g. AKAP12) have been identified as ARE-driven genes (Liu et al. 2017). Kinase and phosphatase-associated E3 ligases such as MID1 and TRIM36 are bona fide AR target genes. MID1 interacts with the kinase PDPK1 and the phosphatase PP2A (Aranda-Orgilles et al. 2011), and thus, potentially providing indirect AR control over their respective phospho-proteomes. TRIM36, on the other hand, is an androgen-induced gene whose overexpression in CaP blocks MEK/ERK signaling, while its decreased activity following ADT increases MEK/ERK kinase transduction pathways (Liang et al. 2018).

Literature indicates that AR can employ also yet other mechanisms to influence the $\mathrm{CaP}$ proteome. One well-known example is AR-dependent activity of several CDKs, which was not captured by the above analyses, 
consistent with its regulation by AR-responsive cyclin expression (Knudsen et al. 1998). It is also conceivable that AR controls enzymatic activity of phosphorylation modulators without altering their expression levels. One such mechanism by which AR may steer kinase activity to specific $\mathrm{CaP}$ functions is its signaling, via activation of RhoA, to the Ser/Thr kinase PKN1, which then mediates androgen control to the secondary transcription factor serum response factor (SRF) (Venkadakrishnan et al. 2019). SRF controls the immediate early response, cell cycle regulation, and organization of cytoskeleton. AR-RhoA-PKN1-mediated activation of SRF signaling is linked with aggressive $\mathrm{CaP}$ behavior and poor outcome (Heemers et al. 2011, Lundon et al. 2017, Prencipe et al. 2018). Interestingly, PKN1 serves also as an AR-associated coregulator, which points toward bidirectional regulation in which AR transactivation is modulated by kinases and phosphatases (Metzger et al. 2008). Review of the RAAR database that contains more than 280 AR-associated coregulators that we compiled before (DePriest et al. 2016) shows that 29 and 6 genes possess kinase and phosphatase moieties, respectively (Tables 1 and 2) (DePriest et al. 2016). Examples include the kinase PRKDC and the phosphatase, CDC25B. Such proteins are part of AR transcriptional complexes at ARE in target genes that are formed in a context-dependent manner, preferentially control subsets of AR target genes and thus aspects of CaP biology (Liu et al. 2017). Differential phosphorylation of transcriptional complex components may underlie some of this specificity (Rasool et al. 2019). Other means of cross-talk between AR and phosphorylation machinery are conceivable, such as AR control of non-coding RNAs (miRNA, eRNA, circRNA) that impact kinase or phosphatase expression.

\section{Mechanisms that involve non-genomic AR function}

It should be noted that all of the scenarios above consider only AR's genomic function, that is, AR exerting its transcription factor function in the cell nucleus. However, non-genomic AR action has been recognized, which involves signal transduction via a membrane-bound or cytoplasmic androgen-activated AR (Zarif \& Miranti 2016, Leung \& Sadar 2017). Non-genomic AR signaling occurs within seconds to minutes, thus much more rapidly than the canonical genomic AR function, and has been shown to activate, for example, Src and MAPK signaling pathways in the cytoplasm (Migliaccio et al. 2000, 2007). These signaling axes have been reported to be constitutively active in CRPC and could thus impact significantly the $\mathrm{CaP}$ phosphoproteome during $\mathrm{CaP}$ progression.
Delineating the full scope of the mechanisms by which AR intersects with CaP phosphorylation events will be important. Even taking into account this limitation and considering only the information provided in Tables 1 and 2, it is obvious that AR can exert major impact on CaP's phosphorylation status: a total of 53 kinases and 22 phosphatases are either controlled by AR or intersect with its signaling. The kinome tree for the impacted kinases shows distribution over seven kinase families, with most enrichment for the CMGC kinase family (Fig. 2) (Metz et al. 2018). AR-associated phosphatases belong to the classes of lipid phosphatases, protein phosphatases and HAD Aspbased phosphatases, while no acid phosphatases, alkaline phosphatases, sugar phosphatases or 5'-nucleotidases are enriched (Fig. 3).

\section{Clinically relevant CaP biology controlled by AR-dependent kinases and phosphatases}

Phosphorylation events control and fine-tune most, if not all, cellular processes. The overview provided in the previous section indicates that $\mathrm{AR}$ action can regulate and involve the activity of dozens of kinases and phosphatases, but the impact of subsequent alterations in downstream phosphorylations on CaP cell behavior and clinical CaP progression has not been explored. Even a superficial glance at the proteins listed in Tables 1 and 2, especially when considering the signaling cascades and substrates that are known to be modified by these at the post-translational level, already predicts that a diverse array of cellular functions is affected. For the purpose of this review, we will focus on those aspects of CaP biology that are most relevant to disease progression and/or are considered for therapeutic intervention.

\section{Cell proliferation and cell cycle regulation}

The ability of cells to proliferate and to progress through the cell cycle is a hallmark of all cancers (Hanahan \& Weinberg 2011). Cell cycle progression is exquisitely regulated by phosphorylation events at critical transition steps, which are tightly controlled by cyclin-CDK interactions. In CaP, one of the best characterized consequences of AR action is control over cell proliferation: lower doses of androgens induce $\mathrm{CaP}$ cell proliferation whereas high doses lead to CaP cell differentiation and/or cell death (Damassa et al. 1991, Zhau et al. 1996, Chuu et al. 2005, Sedelaar \& Isaacs 2009, Denmeade \& Isaacs 2010). Although the molecular mechanism(s) by which AR controls CaP cell proliferation 


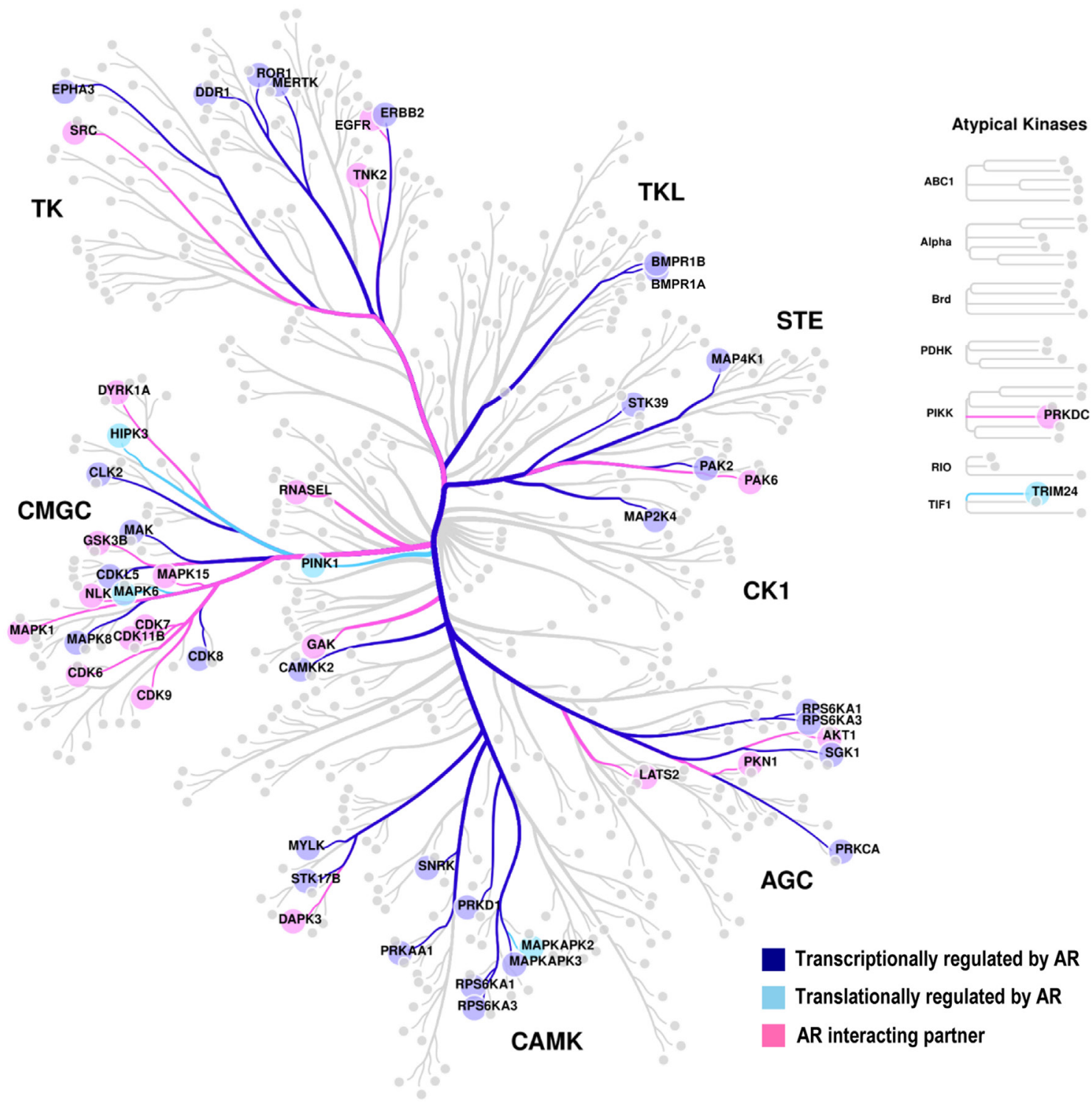

Figure 2

Kinome tree for AR-associated kinases. Kinases transcriptionally regulated by AR are marked in dark blue, kinases translationally regulated by AR in sky blue, and AR-interacting partners in pink. Figure generated using online tool, CORAL (Mets et al. 2018).

remains incompletely understood (Balk \& Knudsen 2008, Schiewer et al. 2012, Wen et al. 2014), biphasic expression patterns and post-translational modifications of regulators of cell cycle checkpoints, particularly at the G1-S phase transition, have long been recognized. Progression from G1 to $S$ phase of the cell cycle following low dose androgen stimulation involves the AR-dependent action of the kinase $\mathrm{CDK} 2,4$, and 6 . CDK6 is listed in Table 1 as AR interactor, and activity of CDK6 as well as these two other CDKs is indirectly regulated by AR via control over cyclin availability (Knudsen et al. 1998). The substrate for the action of CDK2, 4 and 6 in AR-controlled cells cycle progression is $\mathrm{Rb}$, with Cdk-dependent $\mathrm{Rb}$ phosphorylation leading to E2F-controlled cell cycle progression (Markey et al. 2002). In addition to these components of the cell cycle machinery, several other kinases or phosphatases that are either transcriptionally or translationally regulated by $\mathrm{AR}$ or are part of the AR interactome at target genes can influence CaP cell proliferation (Table 1). These include multiple kinases that act at different levels of MAP kinase signaling cascades, for which substrates are not as well known, and may mediate resistance to CDK4/6 inhibition (de Leeuw et al. 2018), as well as regulators of MAPK activity, such as RPS6KA1
(C) 2020 Society for Endocrinology Published by Bioscientifica Ltd. Printed in Great Britain 
Figure 3

Classification of AR-associated phosphatases. and RPS6KA3. In addition, ERBB2, AKT/PI3K, SGK3 signaling have all also been described to impact CaP cell proliferation (Shanmugam et al. 2007, Sherk et al. 2008, Edlind \& Hsieh 2014, Gao et al. 2016). Changes in activity and expression of the tumor suppressor and phosphatase PTEN, both transcriptionally regulated by AR and an AR interactor, are well known to alter $\mathrm{CaP}$ cell proliferation and aggressiveness (Wang et al. 2003).

\section{Cytoskeleton organization and function}

Successful completion of cell division, the final step of cell proliferation, involves spindle formation and reorganization of microtubules, which rely on tightly regulated phosphorylation events. The potential role for AR control over these modifications in CaP cells have yet to be examined. None-the-less, changes in organization and remodeling of the (actin) cytoskeleton are among the most common alterations observed in CaP compared to benign prostate tissues (Purnell et al. 1987, Hemstreet et al. 2000, Haffner et al. 2017). Such alterations also underlie each step of the invasion-metastatic cancer cascade, another key hallmark of cancer (Hanahan \& Weinberg 2011), that starts from local invasion, intravasation and extravasation of cancer cells leading to micrometastases, which develop into macroscopic metastatic cancers. Several of the proteins listed in Tables 1 and 2 play role in these key steps. For instance, DDR1, discoidin domain receptor tyrosine kinase 1 , is a collagen-induced receptor that activates signal transduction pathways involved in cell adhesion, proliferation, and extracellular matrix remodeling (Lee et al. 2019). Its family member DDR2 was shown to play an essential role in CaP bone metastasis and its silencing decreased CaP cell motility and invasiveness (Yan et al. 2014). Consistent with such a role, inhibition of DDR1 reduced EMT, linked to invasive/ metastatic properties, in CaP (Maeyama et al. 2008, Yeh et al. 2011, Koh et al. 2015). Another AR controlled kinase, MERTK is well known to promote phagocytosis of apoptotic cells and reduce cytokine response (Graham et al. 2014) and to drive invasion and metastasis in melanoma (Schlegel et al. 2013), glioblastoma (Wang et al. 2013) as well as CaP (Faltermeier et al. 2016). Although the kinase MYLK is poorly studied in CaP, because of its involvement in phosphorylating myosin light chains and therefore, cytoskeletal reorganization (Zhi et al. 2005), it is anticipated to similarly impact CaP biology. PAK2 is known to phosphorylate MAPK4, MAPK6 and activate MAPKAPK5 to influence F-actin polymerization, induce cytoskeleton reorganization and cell migration (De la Mota-Peynado et al. 2011, Li et al. 2011, Wang et al. 2018). Other examples include PRKD1 (Luef et al. 2016), which negatively regulates cell migration, and MAPKAPK2, which along with HSP27 increased matrix metaloprotease type 2 (MMP2) activity, leading increased cell invasion (Xu et al. 2006). 


\section{Transcriptional control}

Progression from normal prostate to treatment-naïve localized $\mathrm{CaP}$ that is responsive to ADT, and then to CRPC is marked by differential gene expression patterns, which involve also considerable shifts in the transcriptomes and cistromes that are controlled by $\mathrm{AR}$, the major driver of $\mathrm{CaP}$ progression (Massie et al. 2011, Sharma et al. 2013, Stelloo et al. 2015). These alterations in gene expression profiles result from epigenetic and transcriptional events in which several of the AR-associated kinases and phosphatases listed above are known to fulfill critical roles. In addition to roles in cell cycle progression, several CDKs that interact with AR have been implicated also in transcription of AR target genes. CDK6 fulfills such dual roles and has been reported to coactivate also strongly transcription by the gain-of-function AR T878A mutant that occurs under selective pressure of ADT and is present in CRPC (Lim et al. 2005). Other CDKS, such as CDK7 and 9 have been mainly implicated in AR-dependent transcription (Lee et al. 2000, Pawar et al. 2018, Itkonen et al. 2019, Rasool et al. 2019). Whether kinase activity is relevant for this is not always clear, as it is necessary for some CDKs and dispensable for others. The target of CDK kinase action can differ also. CDK7 interacts with the N-terminal of $\mathrm{AR}$, but has not reported to directly phosphorylate AR (Lee et al. 2000). Instead, CDK7 phosphorylates the MED1 component of Mediator complex, which enhances MED1 interaction with AR. Inhibition of CDK7 using a specific inhibitor (TZH1) blocks MED1 recruitment to chromatin (Rasool et al. 2019). On the other hand, CDK9 phosphorylates AR at serine 81 (Gordon et al. 2010), and a kinase-dead version of CDK9 impairs AR transactivation (Lee et al. 2001). Consistent with roles for several CDKs in regulating AR transactivation, also CDC25A and CDC25B, phosphatases that control CDK activity, can modulate transcription of AR target genes (Balk \& Knudsen 2008, Chiu et al. 2009). Whether this entails CDC's phosphatase activity or alterations in phosphorylation of AR or associated transcriptional regulators is not known. Other classes of kinases and phosphatases have been implicated in AR transcriptional control. Functionally diverse coregulators such as HIPK3 aka ANPK (androgen receptor-interacting nuclear protein) or DAPK3 interact with $\mathrm{AR}$ and activate its transcriptional function but AR has not been shown to be a direct substrate of HIPK3 or DAPK3 (Moilanen et al. 1998, Leister et al. 2008, Felten et al. 2013). AKT1, whose activation and activity is a major issue during endocrine therapy in CaP (Carver et al. 2011), does phosphorylate AR at S210 and S790
(Lin et al. 2001), which leads to suppression of AR-target genes such as p21. PAK6-AR interaction (Yang et al. 2001, Lee et al. 2002) also impacts AR target gene transcription and relies on PAK6's kinase domain and PAK6-dependent phosphorylation of AR's DNA-binding domain (DBD) domain (Schrantz et al. 2004). Direct phosphorylation and activation of AR by SRC sensitizes AR to intracrine androgen levels, resulting in the engagement of canonical and non-canonical AR-dependent gene signatures (Guo et al. 2006, Chattopadhyay et al. 2017). We identified the histone phosphatase PGAM5 as integral and essential part of AR transcriptional complexes that contain also p53 and the AR-associated coregulator WDR77 and preferentially control CaP cell proliferation and survival (Liu et al. 2017). Whether this involves PGAM5's phosphatase function was not addressed. Other contributions of the AR-controlled phospho-regulators to the CaP transcriptome are conceivable. As an example, CLK2 is a transcriptionally AR-dependent kinase (Jin et al. 2013) that regulates the spliceosomal complex and alternative splicing in breast cancer and endothelial cells (Eisenreich et al. 2009, Yoshida et al. 2015), suggesting it may influence the spectrum of splice forms expressed.

\section{The clinically relevant AR-dependent CaP phosphoproteome}

The development of kinase inhibitors and their subsequent therapeutic success in other human malignancies such as non-small-cell lung cancer or melanoma (Lynch et al. 2004, Chapman et al. 2011, Shaw et al. 2014) was triggered by observations of activating kinase mutations and/or amplifications. These alterations rendered the kinase function oncogenic and turned it into a driver of cancer progression. In $\mathrm{CaP}$, such somatic alterations in genes encoding kinases or for that matter phosphatases (except PTEN) are rare: only 0.9 to 8 percent (5226 specimens examined via cBioportal) of the AR-dependent phosphorylation regulators listed in Tables 1 and 2 are affected, with the exception of PTEN deletion, which occurs in $18 \%$ of cases/specimens (Fig. 4). The absence of comprehensive phospho-proteomics data from clinical CRPC cases further impeded the evaluation of wild-type kinases as valid therapeutic targets and kinase inhibitors as potential novel therapeutics in CaP. Some smaller scale phospho-proteome studies had been conducted using $\mathrm{CaP}$ cell lines (Giorgianni et al. 2007) and xenograft models under conditions that represent ADT-naïve CaP and CRPC (Ramroop et al. 2018). Results suggested active signaling by several kinases, including for instance YAP1 and the 


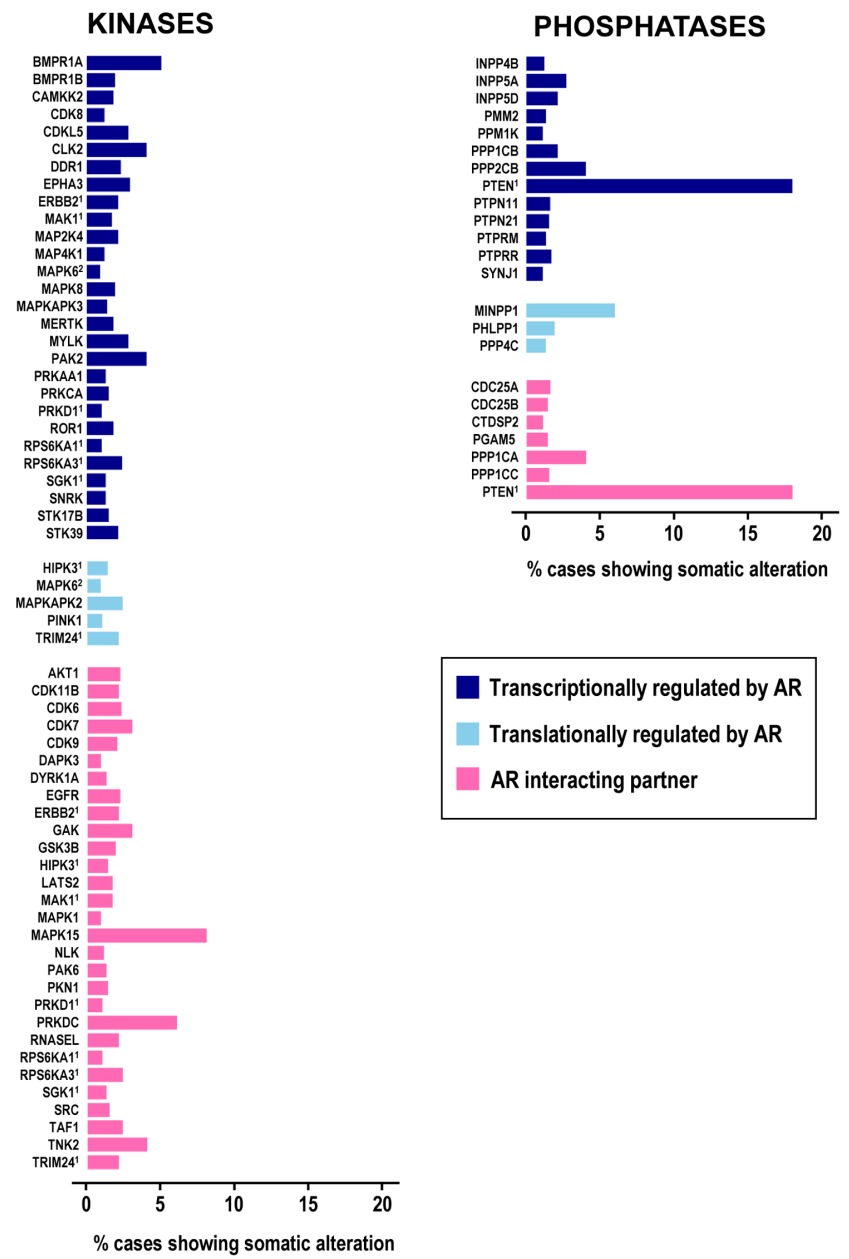

Figure 4

Somatic alterations in AR-associated kinases and phosphatases.

Percentage of clinical CaP cases with somatic alterations in AR-associated kinases (left panel) and phosphatases (right panel). Data reflect results for cBioportal analyses on $5226 \mathrm{CaP}$ specimens.

AR-dependent PAK2, which were put forward as novel viable therapeutic targets (Jiang et al. 2015). Other studies had also recognized that AR can repress major proliferative kinase signaling pathways in $\mathrm{CaP}$, and conversely that ADT can, depending on one's perspective, either cause unwanted activation of these pathways in CRPC or render these kinases as targets for novel CRPC treatments. The most prominent example is ADT-induced activation of PI3K/AKT signaling, may impact downstream kinase signaling such as that mediated by SGK1 (Carver et al. 2011, Toska et al. 2019). Similar observation have been made for the tyrosine kinase BMX. BMX expression in $\mathrm{CaP}$ is suppressed by AR and rapidly increased in response to ADT. BMX contributed to CRPC development in vitro and in vivo by positively regulating the activities of multiple receptor tyrosine kinases, such as MET, FGFR1 (Chen et al. 2013). Inhibition of BMX kinase activity markedly enhanced the response to castration in CaP models (Chen et al. 2018). These studies put forward the concept that modulation of AR activity during CRPC progression may alter the kinase signaling pathways and associated biology that are active in a patient's CaP.

None-the-less, it was not until the concept of personalized medicine gained traction in the $\mathrm{CaP}$ field that more in-depth proteomic analysis on clinical $\mathrm{CaP}$ specimens were undertaken and activity of some wildtype kinases started to emerge as valid targets for new CaP treatment schemes. A 2012 paper from the Witte group laid the foundation by performing immunohistochemistry for tyrosine phosphorylation marks in patient samples representing progression from benign prostate to CRPC and tissues from a mouse $\mathrm{CaP}$ model driven by oncogenes such as AKT, ERG, AR, or K-RASG12V, which showed increased tyrosine phosphorylation marks during both patient and mouse cancer progression (Drake et al. 2012). Subsequent use of phospho-antibodies and mass spectrometry on phospho-tyrosine peptides indicated differential activation of the EGFR, EPHA2, JAK2, SRC and ABL1 tyrosine kinases between these models. These results were the first to suggest that, based on the proteomics footprint of an individual patient's CaP specimen, inhibition of tyrosine kinase, include the AR-dependent EGFR and SRC, could be administered as personalized therapeutics (Drake et al. 2012). Follow-up studies suggesting that kinase activity patterns were similar among the different $\mathrm{CaP}$ metastases within the same patient, but differed between patients, increased the attractiveness of this possibility- although the authors indicate some caution since the relatively small number of specimens studied $(n=16)$ may have led this particular study to be somewhat underpowered (Drake et al. 2016). None-the-less, a more comprehensive analysis of clinical samples that involved mass spectrometry on phospho-tyrosine peptides as well as phospho-serine/ phospho-threonine-peptides, in combination with genomic and transcriptome analyses and sophisticated bioinformatics tools again confirmed differentially activated kinases in CRPC progression. In the same study, an online portal 'pCHIPS' was developed and made publically available as a tool that can define the druggable kinase pathways for drug prioritization in individual patients. Several analyses in the latter study pointed to cell cycle progression, cell migration and AR function as associated with phopsho-proteome alterations and point to wild-type not somatically altered kinases, some of which AR-dependent, being the major determinants of CRPC progression (Drake et al. 2016). 
Table 3 Overview of clinical trials targeting kinases in metastatic CaP.

\begin{tabular}{|c|c|c|}
\hline $\begin{array}{l}\text { Kinase functional } \\
\text { class }\end{array}$ & $\begin{array}{l}\text { Number of } \\
\text { trials }\end{array}$ & Trial acronym \\
\hline $\begin{array}{l}\text { Growth factor } \\
\text { receptors }\end{array}$ & 99 & $\begin{array}{l}\text { INV342, ARS, KHLAD, NRR, } \\
\text { GeniPro, QUERGEN, GCP, P1, } \\
\text { AZD2171IL/0003, ARCAP, PROSUT, } \\
\text { SUN 1120, SMART }\end{array}$ \\
\hline Tyrosine kinases & 14 & BrUOG PR255, READY, PROACT \\
\hline $\begin{array}{l}\text { Cell cycle } \\
\text { regulators }\end{array}$ & 11 & \\
\hline $\begin{array}{l}\text { Akt/mTOR } \\
\text { pathway }\end{array}$ & 9 & \\
\hline Other & 2 & \\
\hline
\end{tabular}

\begin{tabular}{ll}
\hline Drug targets & $\begin{array}{l}\text { Clinical trial } \\
\text { phase }\end{array}$ \\
\hline $\begin{array}{l}\text { VEGFR, PDGFR, FGFR, EGFR, } \\
\text { BCR-ABL, KIT, }\end{array}$ & $\begin{array}{c}\text { Phase 1, } \\
\text { phase 2 }\end{array}$
\end{tabular}

ALK, ROS1, BCR-ABL, SRC, MEK1, MEK2

ATR, AURKA, CDK4, CDK6, CDK9, CHEK1, CHEK2 AKT1, FKBP12, MNK1, MNK2, MTOR, CRTC2, PIK3CA, PI3KCB, PRKDC FAK, PYK2, PIM1
Phase 1, phase 2 Phase 1 , phase 2

Phase 1, phase 2 Phase 1, phase 2

Columns indicate class of kinases, number of clinical trials, acronyms of clinical trials (if any), drug targets, and phases of clinical trials. Kinases marked in bold and italics are present in Table 1. Note that 2 clinical trials relating to precision medicine (MATCH and SMMART) were left out; these target several kinases based on the patient's genotype. An elaborate version of the table can be found in Supplementary Table 1.

The possibility that wild-type kinase action can induce aggressive CaP behavior was consistent with the results from a functional screen in which the impact of 125 kinases that show either increased mRNA expression, gene amplification or increased protein levels in human $\mathrm{CaP}$ on experimental metastasis was examined (Faltermeier et al. 2016). In an in vivo screen, these kinases were overexpressed in murine prostate cells that were tailvein injected into mice that were subsequently screened for lung metastasis. Twenty of these kinases, namely MAP3K8, NTRK2, ARAF, BRAF, CRAF, MAP2K15, MERTK, FGFR3, FLT3, LYN, MAP3K2, NTRK3, PI3KCa, EGFR, EPHA2, HER2, PDGFRa, FGFR1, SRC, BMX (note again some AR-dependent kinases) (Tables 1 and 2) were able to induce such metastasis. Further validation efforts using human prostate cells validated ARAF, BRAF, CRAF, MERTK and NTRK2 as key drivers of bone and visceral tissue metastasis although overexpressing the kinases might not directly correlate to activation of the kinase, and the focus on bone metastasis as endpoint limits implication of kinases involved in treatment resistance in CaP.

\section{Targeting AR-dependent phosphorylation as CaP treatment strategy}

The therapeutic successes obtained with kinase inhibition in other human malignancies have led to clinical testing of several kinase inhibitors for CaP treatment. A search of the clinicaltrial.gov site, a database of privately and publicly funded clinical studies, using the terms 'prostate cancer' and 'kinase inhibitor' returned 137 clinical trials which are listed in Supplementary Table 2. The kinase targets for the inhibitors tested fall into 5 broad classes, namely growth factor receptors, tyrosine kinases, cell cycle regulators, Akt/mTOR pathway-related kinases and others (Table 3). These include several kinases that are AR-associated, such as EGFR, SRC, CDK6, CDK9, and PRKDC.

To date, the success of completed trials testing kinase inhibitors as $\mathrm{CaP}$ therapeutics has been modest and none of the inhibitors tested have moved into routine clinical practice. Several factors may have contributed to the clinical failure of inhibitors that were successful in preclinical therapeutics studies. Notably, recent studies combining phospho-peptide enrichment with mass spectrometry have shown that CaP cell lines and xenografts poorly model the phospho-proteome present in clinical CaP specimens (Drake et al. 2016). These findings imply that the experimental models used to testing the inhibitor do not fully capture the clinical setting they were used in. In addition, these trials also recruited patients without stratifying them based on the proteomic make-up of their $\mathrm{CaP}$, and thus without knowing the activation status of the kinase being targeted. This approach still leaves the possibility of therapeutic success in a subset of patients with the right target activation (i.e. the outliers, or exceptional responders) that is not reflected in the overall negative trial results obtained for entire patient cohort. Another well-known limitation of most kinase inhibitors is their lack of selectively aka polypharmacology: that is the inhibitor is able to inhibit more than one kinase target often at similar IC50s (Davis et al. 2011, Klaeger et al. 2017). This can be especially problematic to the success of a treatment when the activity of the target kinase(s) in the patient is not known and when affected kinases have
C) 2020 Society for Endocrinology Published by Bioscientifica Ltd. Printed in Great Britain 
opposite effects on the same CaP pathways or biology. Another important and often underappreciated limitation is that the endpoint used to measure therapeutic success is not adequate for the compound under investigation, leaving investigators essentially unable to judge the efficacy of drugs tested and to misinterpret trial results. An example of this relates to our and others' testing of the multi-kinase inhibitor, lestaurtinib, as $\mathrm{CaP}$ therapeutic (Venkadakrishnan et al. 2019). Lestaurtinib also inhibits the kinase activity of PKN1, which drives CaP progression, and is highly expressed and activated in CRPC. Lestaurtinib had been well tolerated in phase I clinical trials for advanced carcinomas (Marshall et al. 2005) and was studied clinically for treatment of myelofibrosis and acute myeloid leukemia (Knapper et al. 2006, Shabbir \& Stuart 2010). To date, two phase II clinical trials using lestaurtinib have been initiated in CRPC patients. Patients were considered responders if they had $>50 \%$ decrease in serum PSA, a surrogate marker of $\mathrm{CaP}$ progression, compared to baseline. No patients met these response criteria. Instead, serum PSA tended to increase during treatment with lestaurtinib and declined when treatment was stopped. The decision not to move lestaurtinib forward clinically in CRPC was made solely based on the failure to meet the endpoint of PSA response. However, studies in vivo and in vitro $\mathrm{CaP}$ models have shown increased PSA production by cells that were growth-arrested by lestaurtinib (Collins et al. 2007, Venkadakrishnan et al. 2019). The implication is that a potentially effective agent to target AR action downstream of activated AR that has a different mechanism of action than traditional ADT and is tolerated by patients was abandoned mainly because of the use of an inappropriate biomarker to evaluate treatment response.

Appreciating the issues that prevented therapeutic successes using kinase inhibitors may help resolve them and increase the likelihood of future therapeutic successes. Targeting the right kinase in the right patient may be achieved via proteomics analysis on one or more of his CaP tissues. Similar genomic CaP characterizations are the premise for personalized medicine approaches, and the basis for patient stratifications into for instance the NCI MATCH trials (Coyne et al. 2017). Improving the specificity of kinase inhibitors relies in part on a better understanding of the kinase activity. Indeed, for most kinases, the full spectrum of substrates has not yet been described, the possibility of tissue or cancer type substrate specificity is under-appreciated or the extent of substrate overlap among kinases is not known. Technical advances may help resolve these limitations. Several approaches including SILAC, TiO2 enrichment of phophoproteins for a label-free quantification, phospho-specificimmunoprecipitation followed by mass spectrometry, motif analyses using phospho-peptide arrays are extensively used to identify substrates and substrates binding motifs (Montoya et al. 2011, Wu et al. 2015, de Oliveira et al. 2016). Integration of such assays with computational modeling and bioinformatics analyses to better define linear and non-linear substrate motifs, and proper in vitro and in vivo validation of substrate phosphorylation sites using not only kinase domains but full-length versions of kinases under investigation, are all likely to expand the bona fide spectrum of kinase substrates. Better knowledge of a kinases substrates or the kinase-substrate interactions will facilitate monitoring kinase-targeting treatment responses. This could be achieved using either relevant phospho-motif-specific antibodies or proximity ligation assays on circulating tumor cells obtained from non-invasive liquid biopsies. A second way to improve inhibitor specificity will rely on our enhanced understanding of kinase inhibitor binding pockets or molecular details on substrate-kinase interactions (de Oliveira et al. 2016), which have been proposed as alternative targets to inhibit kinase activity using peptides or peptidomimetics. For many kinases, reliable 3D structural models are not available and crystallization efforts with inhibitors have not yet been undertaken. Ongoing advances in cryoEM are expected to provide this much-needed information.

\section{Conclusions}

The majority of the more than $30,000 \mathrm{CaP}$ deaths annually in the United States are due to failure of ADT, which prevents ligand-activation of AR. Despite an initial remission, CaP progresses while continuing to rely on AR action, emphasizing the need for novel druggable targets downstream of activated AR. Our literature review uncovered that $\mathrm{AR}$ associates with dozens of functionally diverse kinases and phosphatases, and that the ensuing phosphorylation events control CaP biology relevant to aggressive CaP progression. Several of these phosphorylation events were reflected in recently recognized alterations in phospho-proteome in late stage CaP. Kinase inhibitors targeting some of these have been clinically tested and could serve as novel therapies that can overcome CaP's resistance to ADT, provided some challenges and limitations related to therapeutic (c) 2020 Society for Endocrinology Published by Bioscientifica Ltd. Printed in Great Britain 
efficiency, target specificity and monitoring of treatment responses are addressed adequately.

\section{Supplementary materials}

This is linked to the online version of the paper at https://doi.org/10.1530/ ERC-20-0048.

\section{Declaration of interest}

The authors declare that there is no conflict of interest that could be perceived as prejudicing the impartiality of this review.

\section{Funding}

This work was supported the National Cancer Institute (grant number CA166440), the Department of Defense Prostate Cancer Research Program (grant number W81XWH-16-1-0404), and a VeloSano 5 pilot Research Award (to $\mathrm{H} \vee \mathrm{H}$ ).

\section{Author contribution statement}

V B V and H V H wrote the manuscript. V B V, S B S and H V H performed literature searches, selected data to be discussed and critically reviewed the manuscript. All authors reviewed and approved the final manuscript.

\section{References}

Aranda-Orgilles B, Rutschow D, Zeller R, Karagiannidis AI, Kohler A, Chen C, Wilson T, Krause S, Roepcke S, Lilley D, et al. 2011 Protein phosphatase 2A (PP2A)-specific ubiquitin ligase MID1 is a sequencedependent regulator of translation efficiency controlling 3-phosphoinositide-dependent protein kinase-1 (PDPK-1). Journal of Biological Chemistry 286 39945-39957. (https://doi.org/10.1074/jbc. M111.224451)

Asangani IA, Dommeti VL, Wang X, Malik R, Cieslik M, Yang R, EscaraWilke J, Wilder-Romans K, Dhanireddy S, Engelke C, et al. 2014 Therapeutic targeting of BET bromodomain proteins in castrationresistant prostate cancer. Nature 510 278-282. (https://doi. org/10.1038/nature13229)

Balk SP \& Knudsen KE 2008 AR, the cell cycle, and prostate cancer. Nuclear Receptor Signaling 6 e001. (https://doi.org/10.1621/nrs.06001)

Bell RM \& Burns DJ 1991 Lipid activation of protein kinase C. Journal of Biological Chemistry 266 4661-4664.

Bollu LR, Mazumdar A, Savage MI \& Brown PH 2017 Molecular pathways: targeting protein tyrosine phosphatases in cancer. Clinical Cancer Research 23 2136-2142. (https://doi.org/10.1158/1078-0432. CCR-16-0934)

Cai C, Wang H, He HH, Chen S, He L, Ma F, Mucci L, Wang Q, Fiore C, Sowalsky AG, et al. 2013 ERG induces androgen receptor-mediated regulation of SOX9 in prostate cancer. Journal of Clinical Investigation 123 1109-1122. (https://doi.org/10.1172/JCI66666)

Carver BS, Chapinski C, Wongvipat J, Hieronymus H, Chen Y, Chandarlapaty S, Arora V, Le C, Koutcher J, Scher H, et al. 2011 Reciprocal feedback regulation of PI3K and androgen receptor signaling in PTEN-deficient prostate cancer. Cancer Cell 19 575-586. (https://doi.org/10.1016/j.ccr.2011.04.008)
Chapman PB, Hauschild A, Robert C, Haanen JB, Ascierto P, Larkin J, Dummer R, Garbe C, Testori A, Maio M, et al. 2011 Improved survival with vemurafenib in melanoma with BRAF V600E mutation. New England Journal of Medicine 364 2507-2516. (https://doi. org/10.1056/NEJMoa1103782)

Chattopadhyay I, Wang J, Qin M, Gao L, Holtz R, Vessella RL, Leach RW \& Gelman IH 2017 Src promotes castration-recurrent prostate cancer through androgen receptor-dependent canonical and non-canonical transcriptional signatures. Oncotarget 8 10324-10347. (https://doi. org/10.18632/oncotarget.14401)

Chen S, Jiang X, Gewinner CA, Asara JM, Simon NI, Cai C, Cantley LC \& Balk SP 2013 Tyrosine kinase BMX phosphorylates phosphotyrosine-primed motif mediating the activation of multiple receptor tyrosine kinases. Science Signaling 6 ra40. (https://doi. org/10.1126/scisignal.2003936)

Chen S, Cai C, Sowalsky AG, Ye H, Ma F, Yuan X, Simon NI, Gray NS \& Balk SP 2018 BMX-mediated regulation of multiple tyrosine kinases contributes to castration resistance in prostate cancer. Cancer Research 78 5203-5215. (https://doi.org/10.1158/0008-5472.CAN-173615)

Chiu YT, Han HY, Leung SC, Yuen HF, Chau CW, Guo Z, Qiu Y, Chan KW, Wang X, Wong YC, et al. 2009 CDC25A functions as a novel Ar corepressor in prostate cancer cells. Journal of Molecular Biology 385 446-456. (https://doi.org/10.1016/j.jmb.2008.10.070)

Chuu CP, Hiipakka RA, Fukuchi J, Kokontis JM \& Liao S 2005 Androgen causes growth suppression and reversion of androgen-independent prostate cancer xenografts to an androgen-stimulated phenotype in athymic mice. Cancer Research 65 2082-2084. (https://doi. org/10.1158/0008-5472.CAN-04-3992)

Ciardiello F \& Tortora G 2008 EGFR antagonists in cancer treatment. New England Journal of Medicine 358 1160-1174. (https://doi. org/10.1056/NEJMra0707704)

Collins C, Carducci MA, Eisenberger MA, Isaacs JT, Partin AW, Pili R, Sinibaldi VJ, Walczak JS \& Denmeade SR 2007 Preclinical and clinical studies with the multi-kinase inhibitor CEP-701 as treatment for prostate cancer demonstrate the inadequacy of PSA response as a primary endpoint. Cancer Biology and Therapy 6 1360-1367. (https:// doi.org/10.4161/cbt.6.9.4541)

Coyne GO, Takebe N \& Chen AP 2017 Defining precision: the precision medicine initiative trials NCI-MPACT and NCI-MATCH. Current Problems in Cancer 41 182-193. (https://doi.org/10.1016/j. currproblcancer.2017.02.001)

Dai C, Heemers H \& Sharifi N 2017 Androgen signaling in prostate cancer. Cold Spring Harbor Perspectives in Medicine 7 a030452. (https:// doi.org/10.1101/cshperspect.a030452)

Damassa DA, Lin TM, Sonnenschein C \& Soto AM 1991 Biological effects of sex hormone-binding globulin on androgen-induced proliferation and androgen metabolism in LNCaP prostate cells. Endocrinology 129 75-84. (https://doi.org/10.1210/endo-129-1-75)

Davis MI, Hunt JP, Herrgard S, Ciceri P, Wodicka LM, Pallares G, Hocker M, Treiber DK \& Zarrinkar PP 2011 Comprehensive analysis of kinase inhibitor selectivity. Nature Biotechnology 29 1046-1051. (https://doi.org/10.1038/nbt.1990)

De La Mota-Peynado A, Chernoff J \& Beeser A 2011 Identification of the atypical MAPK Erk3 as a novel substrate for p21-activated kinase (Pak) activity. Journal of Biological Chemistry 286 13603-13611. (https://doi.org/10.1074/jbc.M110.181743)

De Leeuw R, Mcnair C, Schiewer MJ, Neupane NP, Brand LJ, Augello MA, Li Z, Cheng LC, Yoshida A, Courtney SM, et al. 2018 MAPK reliance via acquired CDK4/6 inhibitor resistance in cancer. Clinical Cancer Research 24 4201-4214. (https://doi. org/10.1158/1078-0432.CCR-18-0410)

De Oliveira PS, Ferraz FA, Pena DA, Pramio DT, Morais FA \& Schechtman D 2016 Revisiting protein kinase-substrate interactions: toward therapeutic development. Science Signaling 9 re3. (https://doi. org/10.1126/scisignal.aad4016) 
Denmeade SR \& Isaacs JT 2010 Bipolar androgen therapy: the rationale for rapid cycling of supraphysiologic androgen/ablation in men with castration resistant prostate cancer. Prostate 70 1600-1607. (https:// doi.org/10.1002/pros.21196)

Depriest AD, Fiandalo MV, Schlanger S, Heemers F, Mohler JL, Liu S \& Heemers HV 2016 Regulators of androgen action resource: a onestop shop for the comprehensive study of androgen receptor action. Database 2016 bav125. (https://doi.org/10.1093/database/bav125)

Drake JM, Graham NA, Stoyanova T, Sedghi A, Goldstein AS, Cai H, Smith DA, Zhang H, Komisopoulou E, Huang J, et al. 2012 Oncogene-specific activation of tyrosine kinase networks during prostate cancer progression. PNAS 109 1643-1648. (https://doi. org/10.1073/pnas.1120985109)

Drake JM, Graham NA, Lee JK, Stoyanova T, Faltermeier CM, Sud S, Titz B, Huang J, Pienta KJ, Graeber TG, et al. 2013 Metastatic castration-resistant prostate cancer reveals intrapatient similarity and interpatient heterogeneity of therapeutic kinase targets. PNAS 110 E4762-E4769. (https://doi.org/10.1073/pnas.1319948110)

Drake JM, Paull EO, Graham NA, Lee JK, Smith BA, Titz B, Stoyanova T, Faltermeier CM, Uzunangelov V, Carlin DE, et al. 2016 Phosphoproteome integration reveals patient-specific networks in prostate cancer. Cell 166 1041-1054. (https://doi.org/10.1016/j. cell.2016.07.007)

Edlind MP \& Hsieh AC 2014 PI3K-AKT-mTOR signaling in prostate cancer progression and androgen deprivation therapy resistance. Asian Journal of Andrology 16 378-386. (https://doi.org/10.4103/1008682X.122876)

Eid S, Turk S, Volkamer A, Rippmann F \& Fulle S 2017 KinMap: a web-based tool for interactive navigation through human kinome data. BMC Bioinformatics 18 16. (https://doi.org/10.1186/s12859016-1433-7)

Eisenreich A, Bogdanov VY, Zakrzewicz A, Pries A, Antoniak S, Poller W, Schultheiss HP \& Rauch U 2009 Cdc2-like kinases and DNA topoisomerase I regulate alternative splicing of tissue factor in human endothelial cells. Circulation Research 104 589-599. (https:// doi.org/10.1161/CIRCRESAHA.108.183905)

Faltermeier CM, Drake JM, Clark PM, Smith BA, Zong Y, Volpe C, Mathis C, Morrissey C, Castor B, Huang J, et al. 2016 Functional screen identifies kinases driving prostate cancer visceral and bone metastasis. PNAS 113 E172-E181. (https://doi.org/10.1073/ pnas.1521674112)

Felten A, Brinckmann D, Landsberg G \& Scheidtmann KH 2013 Zipperinteracting protein kinase is involved in regulation of ubiquitination of the androgen receptor, thereby contributing to dynamic transcription complex assembly. Oncogene 32 4981-4988. (https:// doi.org/10.1038/onc.2012.503)

Gao S, Ye H, Gerrin S, Wang H, Sharma A, Chen S, Patnaik A, Sowalsky AG, Voznesensky O, Han W, et al. 2016 ErbB2 signaling increases androgen receptor expression in abiraterone-resistant prostate cancer. Clinical Cancer Research 22 3672-3682. (https://doi. org/10.1158/1078-0432.CCR-15-2309)

Giorgianni F, Zhao Y, Desiderio DM \& Beranova-Giorgianni S 2007 Toward a global characterization of the phosphoproteome in prostate cancer cells: identification of phosphoproteins in the LNCaP cell line. Electrophoresis 28 2027-2034. (https://doi.org/10.1002/ elps.200600782)

Gordon V, Bhadel S, Wunderlich W, Zhang J, Ficarro SB, Mollah SA, Shabanowitz J, Hunt DF, Xenarios I, Hahn WC, et al. 2010 CDK9 regulates AR promoter selectivity and cell growth through serine 81 phosphorylation. Molecular Endocrinology 24 2267-2280. (https://doi. org/10.1210/me.2010-0238)

Graham DK, Deryckere D, Davies KD \& Earp HS 2014 The TAM family: phosphatidylserine sensing receptor tyrosine kinases gone awry in cancer. Nature Reviews: Cancer 14 769-785. (https://doi.org/10.1038/ nrc3847)
Groner AC, Cato L, De Tribolet-Hardy J, Bernasocchi T, Janouskova H, Melchers D, Houtman R, Cato ACB, Tschopp P, Gu L, et al. 2016 TRIM24 is an oncogenic transcriptional activator in prostate cancer. Cancer Cell 29 846-858. (https://doi.org/10.1016/j.ccell.2016.04.012)

Guo Z, Dai B, Jiang T, Xu K, Xie Y, Kim O, Nesheiwat I, Kong X, Melamed J, Handratta VD, et al. 2006 Regulation of androgen receptor activity by tyrosine phosphorylation. Cancer Cell $\mathbf{1 0}$ 309-319. (https://doi.org/10.1016/j.ccr.2006.08.021)

Haffner MC, Esopi DM, Chaux A, Gurel M, Ghosh S, Vaghasia AM, Tsai H, Kim K, Castagna N, Lam H, et al. 2017 AIM1 is an actinbinding protein that suppresses cell migration and micrometastatic dissemination. Nature Communications 8 142. (https://doi. org/10.1038/s41467-017-00084-8)

Hanahan D \& Weinberg RA 2011 Hallmarks of cancer: the next generation. Cell 144 646-674. (https://doi.org/10.1016/j. cell.2011.02.013)

Heemers HV, Verhoeven G \& Swinnen JV 2006 Androgen activation of the sterol regulatory element-binding protein pathway: current insights. Molecular Endocrinology 20 2265-2277. (https://doi. org/10.1210/me.2005-0479)

Heemers HV, Schmidt LJ, Sun Z, Regan KM, Anderson SK, Duncan K, Wang D, Liu S, Ballman KV \& Tindall DJ 2011 Identification of a clinically relevant androgen-dependent gene signature in prostate cancer. Cancer Research 71 1978-1988. (https://doi.org/10.1158/00085472.CAN-10-2512)

Hemstreet 3rd GP, Bonner RB, Hurst RE, Bell D \& Bane BL 2000 Abnormal G-actin content in single prostate cells as a biomarker of prostate cancer. Cancer Detection and Prevention 24 464-472.

Hodgson MC, Shao LJ, Frolov A, Li R, Peterson LE, Ayala G, Ittmann MM, Weigel NL \& Agoulnik IU 2011 Decreased expression and androgen regulation of the tumor suppressor gene INPP4B in prostate cancer. Cancer Research $\mathbf{7 1}$ 572-582. (https://doi. org/10.1158/0008-5472.CAN-10-2314)

Hodgson MC, Deryugina EI, Suarez E, Lopez SM, Lin D, Xue H, Gorlov IP, Wang Y \& Agoulnik IU 2014 INPP4B suppresses prostate cancer cell invasion. Cell Communication and Signaling 1261. (https://doi.org/10.1186/s12964-014-0061-y)

Huggins C \& Hodges CV 2002 Studies on prostatic cancer: I. The effect of castration, of estrogen and of androgen injection on serum phosphatases in metastatic carcinoma of the prostate. 1941. Journal of Urology 168 9-12. (https://doi.org/10.1016/s00225347(05)64820-3)

Itkonen HM, Poulose N, Walker S \& Mills IG 2019 CDK9 inhibition induces a metabolic switch that renders prostate cancer cells dependent on fatty acid oxidation. Neoplasia 21 713-720. (https:// doi.org/10.1016/j.neo.2019.05.001)

Janjigian YY, Smit EF, Groen HJ, Horn L, Gettinger S, Camidge DR, Riely GJ, Wang B, Fu Y, Chand VK, et al. 2014 Dual inhibition of EGFR with afatinib and cetuximab in kinase inhibitor-resistant EGFR-mutant lung cancer with and without T790M mutations. Cancer Discovery 4 1036-1045. (https://doi.org/10.1158/2159-8290. CD-14-0326)

Jeitany M, Leroy C, Tosti P, Lafitte M, Le Guet J, Simon V, Bonenfant D, Robert B, Grillet F, Mollevi C, et al. 2018 Inhibition of DDR1-BCR signalling by nilotinib as a new therapeutic strategy for metastatic colorectal cancer. EMBO Molecular Medicine 10 e7918. (https://doi. org/10.15252/emmm.201707918)

Jiang N, Hjorth-Jensen K, Hekmat O, Iglesias-Gato D, Kruse T, Wang C, Wei W, Ke B, Yan B, Niu Y, et al. 2015 In vivo quantitative phosphoproteomic profiling identifies novel regulators of castrationresistant prostate cancer growth. Oncogene 34 2764-2776. (https:// doi.org/10.1038/onc.2014.206)

Jin HJ, Kim J \& Yu J 2013 Androgen receptor genomic regulation. Translational Andrology and Urology 2 157-177. (https://doi. org/10.3978/j.issn.2223-4683.2013.09.01) (c) 2020 Society for Endocrinology Published by Bioscientifica Ltd. Printed in Great Britain 
Karacosta LG, Foster BA, Azabdaftari G, Feliciano DM \& Edelman AM 2012 A regulatory feedback loop between $\mathrm{Ca} 2+/$ calmodulindependent protein kinase kinase 2 (CaMKK2) and the androgen receptor in prostate cancer progression. Journal of Biological Chemistry 287 24832-24843. (https://doi.org/10.1074/jbc. M112.370783)

Klaeger S, Heinzlmeir S, Wilhelm M, Polzer H, Vick B, Koenig PA, Reinecke M, Ruprecht B, Petzoldt S, Meng C, et al. 2017 The target landscape of clinical kinase drugs. Science $\mathbf{3 5 8}$ eaan4368. (https://doi. org/10.1126/science.aan4368)

Knapper S, Burnett AK, Littlewood T, Kell WJ, Agrawal S, Chopra R, Clark R, Levis MJ \& Small D 2006 A phase 2 trial of the FLT3 inhibitor lestaurtinib (CEP701) as first-line treatment for older patients with acute myeloid leukemia not considered fit for intensive chemotherapy. Blood 108 3262-3270. (https://doi.org/10.1182/blood2006-04-015560)

Knudsen KE, Arden KC \& Cavenee WK 1998 Multiple G1 regulatory elements control the androgen-dependent proliferation of prostatic carcinoma cells. Journal of Biological Chemistry 273 20213-20222. (https://doi.org/10.1074/jbc.273.32.20213)

Koh M, Woo Y, Valiathan RR, Jung HY, Park SY, Kim YN, Kim HR, Fridman R \& Moon A 2015 Discoidin domain receptor 1 is a novel transcriptional target of ZEB1 in breast epithelial cells undergoing $\mathrm{H}$-Ras-induced epithelial to mesenchymal transition. International Journal of Cancer 136 E508-E520. (https://doi.org/10.1002/ijc.29154)

Kumari S, Senapati D \& Heemers HV 2017 Rationale for the development of alternative forms of androgen deprivation therapy. Endocrine-Related Cancer 24 R275-R295. (https://doi.org/10.1530/ ERC-17-0121)

Lee DK, Duan HO \& Chang C 2000 From androgen receptor to the general transcription factor TFIIH. Identification of CDK activating kinase (CAK) as an androgen receptor $\mathrm{NH}(2)$-terminal associated coactivator. Journal of Biological Chemistry 275 9308-9313. (https:// doi.org/10.1074/jbc.275.13.9308)

Lee DK, Duan HO \& Chang C 2001 Androgen receptor interacts with the positive elongation factor P-TEFb and enhances the efficiency of transcriptional elongation. Journal of Biological Chemistry 276 9978-9984. (https://doi.org/10.1074/jbc.M002285200)

Lee SR, Ramos SM, Ko A, Masiello D, Swanson KD, Lu ML \& Balk SP $2002 \mathrm{AR}$ and ER interaction with a p21-activated kinase (PAK6). Molecular Endocrinology 16 85-99. (https://doi.org/10.1210/ mend.16.1.0753)

Lee YC, Kurtova AV, Xiao J, Nikolos F, Hayashi K, Tramel Z, Jain A, Chen F, Chokshi M, Lee C, et al. 2019 Collagen-rich airway smooth muscle cells are a metastatic niche for tumor colonization in the lung. Nature Communications 10 2131. (https://doi.org/10.1038/ s41467-019-09878-4)

Leister P, Felten A, Chasan AI \& Scheidtmann KH 2008 ZIP kinase plays a crucial role in androgen receptor-mediated transcription. Oncogene 27 3292-3300. (https://doi.org/10.1038/sj.onc.1210995)

Leung JK \& Sadar MD 2017 Non-genomic actions of the androgen receptor in prostate cancer. Frontiers in Endocrinology 8 2. (https://doi. org/10.3389/fendo.2017.00002)

Li J, Yen C, Liaw D, Podsypanina K, Bose S, Wang SI, Puc J, Miliaresis C, Rodgers L, Mccombie R, et al. 1997 PTEN, a putative protein tyrosine phosphatase gene mutated in human brain, breast, and prostate cancer. Science 275 1943-1947. (https://doi.org/10.1126/ science.275.5308.1943)

Li P, Nicosia SV \& Bai W 2001 Antagonism between PTEN/MMAC1/ TEP-1 and androgen receptor in growth and apoptosis of prostatic cancer cells. Journal of Biological Chemistry 276 20444-20450. (https://doi.org/10.1074/jbc.M010226200)

Li T, Zhang J, Zhu F, Wen W, Zykova T, Li X, Liu K, Peng C, Ma W, Shi G, et al. 2011 P21-activated protein kinase (PAK2)-mediated c-Jun phosphorylation at 5 threonine sites promotes cell transformation. Carcinogenesis 32 659-666. (https://doi.org/10.1093/ carcin/bgq271)

Liang C, Wang S, Qin C, Bao M, Cheng G, Liu B, Shao P, Lv Q, Song N, Hua L, et al. 2018 TRIM36, a novel androgen-responsive gene, enhances anti-androgen efficacy against prostate cancer by inhibiting MAPK/ERK signaling pathways. Cell Death and Disease 9 155. (https://doi.org/10.1038/s41419-017-0197-y)

Lim JT, Mansukhani M \& Weinstein IB 2005 Cyclin-dependent kinase 6 associates with the androgen receptor and enhances its transcriptional activity in prostate cancer cells. PNAS $\mathbf{1 0 2}$ 5156-5161. (https://doi.org/10.1073/pnas.0501203102)

Lin HK, Yeh S, Kang HY \& Chang C 2001 Akt suppresses androgeninduced apoptosis by phosphorylating and inhibiting androgen receptor. PNAS 98 7200-7205. (https://doi.org/10.1073/ pnas.121173298

Liu S, Kumari S, Hu Q, Senapati D, Venkadakrishnan VB, Wang D, Depriest AD, Schlanger SE, Ben-Salem S, Valenzuela MM, et al. 2017 A comprehensive analysis of coregulator recruitment, androgen receptor function and gene expression in prostate cancer. eLife $\mathbf{6}$ e28482. (https://doi.org/10.7554/eLife.28482)

Liu Y, Horn JL, Banda K, Goodman AZ, Lim Y, Jana S, Arora S, Germanos AA, Wen L, Hardin WR, et al. 2019 The androgen receptor regulates a druggable translational regulon in advanced prostate cancer. Science Translational Medicine 11 eaaw4993. (https://doi. org/10.1126/scitranslmed.aaw4993)

Luef B, Handle F, Kharaishvili G, Hager M, Rainer J, Janetschek G, Hruby S, Englberger C, Bouchal J, Santer FR, et al. 2016 The AR/ NCOA1 axis regulates prostate cancer migration by involvement of PRKD1. Endocrine-Related Cancer 23 495-508. (https://doi. org/10.1530/ERC-16-0160)

Lundon DJ, Boland A, Prencipe M, Hurley G, O'neill A, Kay E, Aherne ST, Doolan P, Madden SF, Clynes M, et al. 2017 The prognostic utility of the transcription factor SRF in docetaxelresistant prostate cancer: in-vitro discovery and in-vivo validation. BMC Cancer 17 163. (https://doi.org/10.1186/s12885-017-3100-4)

Lynch TJ, Bell DW, Sordella R, Gurubhagavatula S, Okimoto RA, Brannigan BW, Harris PL, Haserlat SM, Supko JG, Haluska FG, et al. 2004 Activating mutations in the epidermal growth factor receptor underlying responsiveness of non-small-cell lung cancer to gefitinib. New England Journal of Medicine 350 2129-2139. (https://doi. org/10.1056/NEJMoa040938)

Maeyama M, Koga H, Selvendiran K, Yanagimoto C, Hanada S, Taniguchi E, Kawaguchi T, Harada M, Ueno T \& Sata M 2008 Switching in discoid domain receptor expressions in SLUG-induced epithelial-mesenchymal transition. Cancer 113 2823-2831. (https:// doi.org/10.1002/cncr.23900)

Makkonen H, Kauhanen M, Jaaskelainen T \& Palvimo JJ 2011 Androgen receptor amplification is reflected in the transcriptional responses of vertebral-cancer of the prostate cells. Molecular and Cellular Endocrinology 331 57-65. (https://doi.org/10.1016/j. mce.2010.08.008)

Markey MP, Angus SP, Strobeck MW, Williams SL, Gunawardena RW, Aronow BJ \& Knudsen ES 2002 Unbiased analysis of RB-mediated transcriptional repression identifies novel targets and distinctions from E2F action. Cancer Research 62 6587-6597.

Marshall JL, Kindler H, Deeken J, Bhargava P, Vogelzang NJ, Rizvi N, Luhtala T, Boylan S, Dordal M, Robertson P, et al. 2005 Phase I trial of orally administered CEP-701, a novel neurotrophin receptorlinked tyrosine kinase inhibitor. Investigational New Drugs 23 31-37. (https://doi.org/10.1023/B:DRUG.0000047103.64335.b0)

Massie CE, Lynch A, Ramos-Montoya A, Boren J, Stark R, Fazli L, Warren A, Scott H, Madhu B, Sharma N, et al. 2011 The androgen receptor fuels prostate cancer by regulating central metabolism and biosynthesis. EMBO Journal 30 2719-2733. (https://doi.org/10.1038/ emboj.2011.158)
C) 2020 Society for Endocrinology Published by Bioscientifica Ltd. Printed in Great Britain 
Metzger E, Yin N, Wissmann M, Kunowska N, Fischer K, Friedrichs N, Patnaik D, Higgins JM, Potier N, Scheidtmann KH, et al. 2008 Phosphorylation of histone $\mathrm{H} 3$ at threonine 11 establishes a novel chromatin mark for transcriptional regulation. Nature Cell Biology 10 53-60. (https://doi.org/10.1038/ncb1668)

Metz KS, Deoudes EM, Berginski ME, Jimenez-Ruiz I, Aksoy BA, Hammerbacher J, Gomez SM \& Phanstiel DH 2018 Coral: clear and customizable visualization of human kinome data. Cell Systems $\mathbf{7}$ 347-350.e1. (https://doi.org/10.1016/j.cels.2018.07.001)

Migliaccio A, Castoria G, Di Domenico M, De Falco A, Bilancio A, Lombardi M, Barone MV, Ametrano D, Zannini MS, Abbondanza C, et al. 2000 Steroid-induced androgen receptor-oestradiol receptor beta-Src complex triggers prostate cancer cell proliferation. EMBO Journal 19 5406-5417. (https://doi.org/10.1093/emboj/19.20.5406)

Migliaccio A, Varricchio L, De Falco A, Castoria G, Arra C, Yamaguchi H, Ciociola A, Lombardi M, Di Stasio R, Barbieri A, et al. 2007 Inhibition of the SH3 domain-mediated binding of Src to the androgen receptor and its effect on tumor growth. Oncogene 26 6619-6629. (https://doi.org/10.1038/sj.onc.1210487)

Mills IG 2014 Maintaining and reprogramming genomic androgen receptor activity in prostate cancer. Nature Reviews: Cancer $\mathbf{1 4}$ 187-198. (https://doi.org/10.1038/nrc3678)

Moilanen AM, Karvonen U, Poukka H, Janne OA \& Palvimo JJ 1998 Activation of androgen receptor function by a novel nuclear protein kinase. Molecular Biology of the Cell 9 2527-2543. (https://doi. org/10.1091/mbc.9.9.2527)

Mok TS, Wu Y-L, Ahn M-J, Garassino MC, Kim HR, Ramalingam SS, Shepherd FA, He Y, Akamatsu H, Theelen WS, et al. 2017 Osimertinib or platinum-pemetrexed in EGFR T790M-positive lung cancer. New England Journal of Medicine 376 629-640. (https://doi. org/10.1056/NEJMoa1612674)

Montoya A, Beltran L, Casado P, Rodriguez-Prados JC \& Cutillas PR 2011 Characterization of a $\mathrm{TiO}(2)$ enrichment method for label-free quantitative phosphoproteomics. Methods 54 370-378. (https://doi. org/10.1016/j.ymeth.2011.02.004)

Munster P, Mita M, Mahipal A, Nemunaitis J, Massard C, Mikkelsen T, Cruz C, Paz-Ares L, Hidalgo M, Rathkopf D, et al. 2019 First-inhuman phase I study of a dual mTOR kinase and DNA-PK inhibitor (CC-115) in advanced malignancy. Cancer Management and Research 11 10463-10476. (https://doi.org/10.2147/CMAR.S208720)

Narayanan S, Srinivas S \& Feldman D 2016 Androgen-glucocorticoid interactions in the era of novel prostate cancer therapy. Nature Reviews: Urology 13 47-60. (https://doi.org/10.1038/ nrurol.2015.254)

Pawar A, Gollavilli PN, Wang S \& Asangani IA 2018 Resistance to BET inhibitor leads to alternative therapeutic vulnerabilities in castrationresistant prostate cancer. Cell Reports 22 2236-2245. (https://doi. org/10.1016/j.celrep.2018.02.011)

Pawson T \& Scott JD 1997 Signaling through scaffold, anchoring, and adaptor proteins. Science 278 2075-2080. (https://doi.org/10.1126/ science.278.5346.2075)

Penfold L, Woods A, Muckett P, Nikitin AY, Kent TR, Zhang S, Graham R, Pollard A \& Carling D 2018 CAMKK2 promotes prostate cancer independently of AMPK via increased lipogenesis. Cancer Research 78 6747-6761. (https://doi.org/10.1158/0008-5472.CAN-180585)

Prencipe M, Fabre A, Murphy TB, Vargyas E, O'neill A, Bjartell A, Tasken KA, Grytli HH, Svindland A, Berge V, et al. 2018 Role of serum response factor expression in prostate cancer biochemical recurrence. Prostate 78 724-730. (https://doi.org/10.1002/ pros.23516)

Purnell DM, Heatfield BM, Anthony RL \& Trump BF 1987 Immunohistochemistry of the cytoskeleton of human prostatic epithelium. Evidence for disturbed organization in neoplasia. American Journal of Pathology 126 384-395.
Ramroop JR, Stein MN \& Drake JM 2018 Impact of phosphoproteomics in the era of precision medicine for prostate cancer. Frontiers in Oncology 8 28. (https://doi.org/10.3389/fonc.2018.00028)

Rasool RU, Natesan R, Deng Q, Aras S, Lal P, Sander Effron S, MitchellVelasquez E, Posimo JM, Carskadon S, Baca SC, et al. 2019 CDK7 inhibition suppresses castration-resistant prostate cancer through MED1 inactivation. Cancer Discovery 9 1538-1555. (https://doi. org/10.1158/2159-8290.CD-19-0189)

Schiewer MJ \& Knudsen KE 2016 Linking DNA damage and hormone signaling pathways in cancer. Trends in Endocrinology and Metabolism 27 216-225. (https://doi.org/10.1016/j.tem.2016.02.004)

Schiewer MJ \& Knudsen KE 2019 DNA damage response in prostate cancer. Cold Spring Harbor Perspectives in Medicine 9 a030486. (https:// doi.org/10.1101/cshperspect.a030486)

Schiewer MJ, Augello MA \& Knudsen KE 2012 The AR dependent cell cycle: mechanisms and cancer relevance. Molecular and Cellular Endocrinology 352 34-45. (https://doi.org/10.1016/j.mce.2011.06.033)

Schlegel J, Sambade MJ, Sather S, Moschos SJ, Tan AC, Winges A, Deryckere D, Carson CC, Trembath DG, Tentler JJ, et al. 2013 MERTK receptor tyrosine kinase is a therapeutic target in melanoma. Journal of Clinical Investigation 123 2257-2267. (https://doi. org/10.1172/JCI67816)

Schrantz N, da Silva Correia J, Fowler B, Ge Q, Sun Z \& Bokoch GM 2004 Mechanism of p21-activated kinase 6-mediated inhibition of androgen receptor signaling. Journal of Biological Chemistry 279 1922-1931. (https://doi.org/10.1074/jbc.M311145200)

Sedelaar JP \& Isaacs JT 2009 Tissue culture media supplemented with $10 \%$ fetal calf serum contains a castrate level of testosterone. Prostate 69 1724-1729. (https://doi.org/10.1002/pros.21028)

Senapati D, Kumari S \& Heemers HV 2019 Androgen receptor co-regulation in prostate cancer. Asian Journal of Urology [epub]. (https://doi.org/10.1016/j.ajur.2019.09.005)

Shabbir M \& Stuart R 2010 Lestaurtinib, a multitargeted tyrosine kinase inhibitor: from bench to bedside. Expert Opinion on Investigational Drugs 19 427-436. (https://doi.org/10.1517/13543781003598862)

Shanmugam I, Cheng G, Terranova PF, Thrasher JB, Thomas CP \& Li B 2007 Serum/glucocorticoid-induced protein kinase-1 facilitates androgen receptor-dependent cell survival. Cell Death and Differentiation 14 2085-2094. (https://doi.org/10.1038/sj. cdd.4402227)

Sharma NL, Massie CE, Ramos-Montoya A, Zecchini V, Scott HE, Lamb AD, Macarthur S, Stark R, Warren AY, Mills IG, et al. 2013 The androgen receptor induces a distinct transcriptional program in castration-resistant prostate cancer in man. Cancer Cell 23 35-47. (https://doi.org/10.1016/j.ccr.2012.11.010)

Shaw AT, Kim DW, Mehra R, Tan DS, Felip E, Chow LQ, Camidge DR, Vansteenkiste J, Sharma S, De Pas T, et al. 2014 Ceritinib in ALKrearranged non-small-cell lung cancer. New England Journal of Medicine 370 1189-1197. (https://doi.org/10.1056/NEJMoa1311107)

Sherk AB, Frigo DE, Schnackenberg CG, Bray JD, Laping NJ, Trizna W, Hammond M, Patterson JR, Thompson SK, Kazmin D, et al. 2008 Development of a small-molecule serum- and glucocorticoidregulated kinase-1 antagonist and its evaluation as a prostate cancer therapeutic. Cancer Research 68 7475-7483. (https://doi. org/10.1158/0008-5472.CAN-08-1047)

Siegel RL, Miller KD \& Jemal A 2020 Cancer statistics, 2020. CA: A Cancer Journal for Clinicians 70 7-30. (https://doi.org/10.3322/ caac.21590)

Sinha A, Huang V, Livingstone J, Wang J, Fox NS, Kurganovs N, Ignatchenko V, Fritsch K, Donmez N, Heisler LE, et al. 2019 The proteogenomic landscape of curable prostate cancer. Cancer Cell $\mathbf{3 5}$ 414.e6-427.e6. (https://doi.org/10.1016/j.ccell.2019.02.005)

Stelloo S, Nevedomskaya E, Van Der Poel HG, De Jong J, Van Leenders GJ, Jenster G, Wessels LF, Bergman AM \& Zwart W 2015 Androgen receptor profiling predicts prostate cancer outcome. EMBO (c) 2020 Society for Endocrinology Published by Bioscientifica Ltd. Printed in Great Britain 
Molecular Medicine 7 1450-1464. (https://doi.org/10.15252/ emmm.201505424)

Sweeney C, Percent IJ, Babu S, Cultrera J, Mehlhaff BA, Goodman OB, Morris D, Schnadig ID, Albany C, Shore ND, et al. 2019 Phase 1b/2 study of enzalutamide (ENZ) with LY3023414 (LY) or placebo (PL) in patients (pts) with metastatic castration-resistant prostate cancer (mCRPC) after progression on abiraterone. Journal of Clinical Oncology 37 5009-5009. (https://doi.org/10.1200/JCO.2019.37.15_ suppl.5009)

Toska E, Castel P, Chhangawala S, Arruabarrena-Aristorena A, Chan C, Hristidis VC, Cocco E, Sallaku M, Xu G, Park J, et al. 2019 PI3K inhibition activates SGK1 via a feedback loop to promote chromatinbased regulation of ER-dependent gene expression. Cell Reports $\mathbf{2 7}$ 294.e5-306.e5. (https://doi.org/10.1016/j.celrep.2019.02.111)

Venkadakrishnan VB, Depriest AD, Kumari S, Senapati D, Ben Salem S, Su Y, Mudduluru G, Hu Q, Cortes E, Pop E, et al. 2019 Protein Kinase N1 control of androgen-responsive serum response factor action provides rationale for novel prostate cancer treatment strategy. Oncogene 38 4496-4511. (https://doi.org/10.1038/s41388019-0732-7)

Waltering KK, Helenius MA, Sahu B, Manni V, Linja MJ, Janne OA \& Visakorpi T 2009 Increased expression of androgen receptor sensitizes prostate cancer cells to low levels of androgens. Cancer Research 69 8141-8149. (https://doi.org/10.1158/0008-5472.CAN-090919)

Wang S, Gao J, Lei Q, Rozengurt N, Pritchard C, Jiao J, Thomas GV, Li G, Roy-Burman P, Nelson PS, et al. 2003 Prostate-specific deletion of the murine Pten tumor suppressor gene leads to metastatic prostate cancer. Cancer Cell 4 209-221. (https://doi.org/10.1016/ s1535-6108(03)00215-0)

Wang Y, Moncayo G, Morin P, Xue G, Grzmil M, Lino MM, ClémentSchatlo V, Frank S, Merlo A \& Hemmings BA 2013 Mer receptor tyrosine kinase promotes invasion and survival in glioblastoma multiforme. Oncogene 32 872-882. (https://doi.org/10.1038/ onc.2012.104)

Wang Y, Zeng C, Li J, Zhou Z, Ju X, Xia S, Li Y, Liu A, Teng H, Zhang K, et al. 2018 PAK2 haploinsufficiency results in synaptic cytoskeleton impairment and autism-related behavior. Cell Reports 24 2029-2041. (https://doi.org/10.1016/j.celrep.2018.07.061)

Wasmuth EV, Hoover EA, Antar A, Klinge S, Chen Y \& Sawyers CL 2020 Modulation of androgen receptor DNA binding activity through direct interaction with the ETS transcription factor ERG. PNAS 117 8584-8592. (https://doi.org/10.1073/pnas.1922159117)

Watson PA, Arora VK \& Sawyers CL 2015 Emerging mechanisms of resistance to androgen receptor inhibitors in prostate cancer. Nature Reviews: Cancer 15 701-711. (https://doi.org/10.1038/nrc4016)

Wen S, Niu Y, Lee SO \& Chang C 2014 Androgen receptor (AR) positive vs negative roles in prostate cancer cell deaths including apoptosis, anoikis, entosis, necrosis and autophagic cell death. Cancer Treatment Reviews 40 31-40. (https://doi.org/10.1016/j.ctrv.2013.07.008)

White MA, Tsouko E, Lin C, Rajapakshe K, Spencer JM, Wilkenfeld SR, Vakili SS, Pulliam TL, Awad D, Nikolos F, et al. 2018 GLUT12 promotes prostate cancer cell growth and is regulated by androgens and CaMKK2 signaling. Endocrine-Related Cancer 25 453-469. (https://doi.org/10.1530/ERC-17-0051)

Wu X, Zahari MS, Renuse S, Nirujogi RS, Kim MS, Manda SS, Stearns V, Gabrielson E, Sukumar S \& Pandey A 2015 Phosphoproteomic analysis identifies focal adhesion kinase 2 (FAK2) as a potential therapeutic target for tamoxifen resistance in breast cancer. Molecular and Cellular Proteomics 14 2887-2900. (https://doi.org/10.1074/mcp. M115.050484)

Xu L, Chen S \& Bergan RC 2006 MAPKAPK2 and HSP27 are downstream effectors of p38 MAP kinase-mediated matrix metalloproteinase type 2 activation and cell invasion in human prostate cancer. Oncogene 25 2987-2998. (https://doi.org/10.1038/sj.onc.1209337)

Xu K, Wu ZJ, Groner AC, He HH, Cai C, Lis RT, Wu X, Stack EC, Loda M, Liu T, et al. 2012 EZH2 oncogenic activity in castrationresistant prostate cancer cells is Polycomb-independent. Science 338 1465-1469. (https://doi.org/10.1126/science.1227604)

Yan Z, Jin S, Wei Z, Huilian H, Zhanhai Y, Yue T, Juan L, Jing L, Libo Y $\&$ Xu L 2014 Discoidin domain receptor 2 facilitates prostate cancer bone metastasis via regulating parathyroid hormone-related protein. Biochimica et Biophysica Acta 1842 1350-1363. (https://doi. org/10.1016/j.bbadis.2014.04.018)

Yang F, Li X, Sharma M, Zarnegar M, Lim B \& Sun Z 2001 Androgen receptor specifically interacts with a novel p21-activated kinase, PAK6. Journal of Biological Chemistry 276 15345-15353. (https://doi. org/10.1074/jbc.M010311200)

Yeh YC, Wu CC, Wang YK \& Tang MJ 2011 DDR1 triggers epithelial cell differentiation by promoting cell adhesion through stabilization of E-cadherin. Molecular Biology of the Cell 22 940-953. (https://doi. org/10.1091/mbc.E10-08-0678)

Yoshida T, Kim JH, Carver K, Su Y, Weremowicz S, Mulvey L, Yamamoto S, Brennan C, Mei S, Long H, et al. 2015 CLK2 is an oncogenic kinase and splicing regulator in breast cancer. Cancer Research 75 1516-1526. (https://doi.org/10.1158/0008-5472.CAN-142443)

Yu J, Yu J, Mani RS, Cao Q, Brenner CJ, Cao X, Wang X, Wu L, Li J, Hu M, et al. 2010 An integrated network of androgen receptor, polycomb, and TMPRSS2-ERG gene fusions in prostate cancer progression. Cancer Cell 17 443-454. (https://doi.org/10.1016/j. ccr.2010.03.018)

Zarif JC \& Miranti CK 2016 The importance of non-nuclear AR signaling in prostate cancer progression and therapeutic resistance. Cellular Signalling 28 348-356. (https://doi.org/10.1016/j.cellsig.2016.01.013)

Zhau HY, Chang SM, Chen BQ, Wang Y, Zhang H, Kao C, Sang QA, Pathak SJ \& Chung LW 1996 Androgen-repressed phenotype in human prostate cancer. PNAS 93 15152-15157. (https://doi. org/10.1073/pnas.93.26.15152)

Zhi G, Ryder JW, Huang J, Ding P, Chen Y, Zhao Y, Kamm KE \& Stull JT 2005 Myosin light chain kinase and myosin phosphorylation effect frequency-dependent potentiation of skeletal muscle contraction. PNAS 102 17519-17524. (https://doi.org/10.1073/ pnas.0506846102)

Received in final form 3 April 2020

Accepted 6 April 2020

Accepted Manuscript published online 6 April 2020 https://erc.bioscientifica.com https://doi.org/10.1530/ERC-20-0048 (c) 2020 Society for Endocrinology Published by Bioscientifica Ltd. Printed in Great Britain 